\title{
Early and Middle Pleistocene Faunal and Hominins Dispersals through Southwestern Asia
}

\section{Citation}

Bar-Yosef, Ofer and Miriam Belmaker. Forthcoming. Early and Middle Pleistocene faunal and hominins dispersals through Southwestern Asia. Quaternary Science Reviews 29.

\section{Published Version}

doi:10.1016/j.quascirev.2010.02.016

\section{Permanent link}

http://nrs.harvard.edu/urn-3:HUL.InstRepos:4270472

\section{Terms of Use}

This article was downloaded from Harvard University's DASH repository, and is made available under the terms and conditions applicable to Open Access Policy Articles, as set forth at http:// nrs.harvard.edu/urn-3:HUL.InstRepos:dash.current.terms-of-use\#OAP

\section{Share Your Story}

The Harvard community has made this article openly available.

Please share how this access benefits you. Submit a story.

Accessibility 
Ofer Bar-Yosef and Miriam Belmaker

Department of Anthropology

Harvard University

$$
\text { Fax ++ } 16174968041
$$


13 This review summarizes the paleoecology of the Early and Middle Pleistocene of

14 southwestern Asia, based on both flora and fauna, retrieved from a series of 'windows'

15 provided by the excavated sites. The incomplete chrono-stratigraphy of this vast region

16 does not allow to accept the direct chronological correlation between the available sites

17 and events of faunal and hominin dispersals from Africa. It also demonstrates that

18 hominins survived in a mixed landscape of open parkland with forested surrounding hills.

19 In addition, the prevailing environmental conditions are not sufficient to explain the

20 differences between 'core and flake' and the Acheulian industries that probably reflect

21 the learned traditions of different groups of hominins successful adaptations to new

22 ecological niches away from the African savanna. The current distribution of lithic

23 industries across Eurasia is undoubtedly incomplete due to lack of cultural continuities as

24 well as paucity of field research in several sub-regions. This observation supports the

25 contention that what we view as a constant stream of migrants was actually interrupted

26 many times. The continuous occupation of southwestern Asia by the makers of the

27 Acheulian is in contrast with neighboring regions such as the Iranian plateau and Eastern

28 Europe. A more complex model is required to explain the Eurasian archaeological-

29 cultural mosaic recorded in Eurasia. 


\section{Introduction}

31 The effect of climate change on the tempo and mode of early hominids dispersals

32 from Africa during the Early and Middle Pleistocene is one of the main interests in

33 paleoanthropology and Paleolithic archaeology (Behrensmeyer, 2006). It has been

34 suggested that the expansion of savanna environments during the Early Pleistocene

35 allowed for the first 'Out of Africa I' dispersal (Dennell, 2004; Martínez-Navarro, 2004)

36 and that humans dispersed into Western Europe during warmer periods and that the

37 dispersal was highly influenced by climate rather than culture, which played only a minor

38 role (Agustí et al., 2009a). However, these theories assume as a working hypotheses that

39 the presence of hominins and faunal present in the paleontological and archaeological

40 record is continuous. Here we would like to focus on southwestern Asia that served as the

41 main corridor for hominin dispersal during the Early and Middle Pleistocene and address

42 the assertion that we can test hominids co-dispersed with other taxa and the extent of the

43 response to climatic forcing. We will propose that there is no correlation between

44 hominid and faunal dispersals and suggest that early Homo dispersals were not directly

45 controlled by climatic forcing.

46 Geological and archaeological investigations in southwestern Asia produced a

47 few "windows" into the geological sequence of the Early and Middle Pleistocene. Most

48 of these "windows" are known from excavations of archaeological sites. Hence, in order

49 to provide a continuous narrative of hominin and faunal dispersals we need to combine

50 the chronologically patchy information with the physiographic variability of this vast

51 region, as well as the incomplete paleo-climatic conditions that determined the

52 distribution of resources in each sub-region. 
The sub-regions of southwestern Asia are commonly identified from north to

54 south and west to east as follows: Anatolia, the southern Caucasus, The Zagros

55 mountains and the Iranian plateau, the Levant and the Arabian peninsula. Among these,

56 due to many years of field and laboratory research, the better known is the Levant. It also

57 has the advantage that researchers from various schools and institutions conducted

58 surveys of Quaternary deposits, drilling boreholes for water and pollen, and

59 archaeological excavations of Lower Paleolithic occupations. Thus the accumulated

60 information creates an imbalance between the areas, some of which like the Iranian and

61 the Anatolian plateaus are of larger area than the Levant but yet poorly known. We are

62 therefore forced to base our review on the Levantine sequence and touch upon, in a more

63 cursory fashion, the other sub-regions.

64 The Levant is a unique biogeographic entity within southwestern Asia. It lies at

65 the crossroads of Africa and Eurasia and has more lush environments compared to the

66 alternative dispersal corridor on the southern fringes of the Arabian Peninsula. This land

67 bridge emerged during the Miocene as a continuous terrestrial belt that allowed various

68 plants and animal taxa to migrate through in either direction (Thomas, 1985; Tchernov,

69 1988; Bar-Yosef, 1994,1998a). The southern path through the margins of the Arabian

70 Peninsula could be crossed at the Bab el-Mandeb straights during low sea level stands,

71 and along the area that receives the summer Indian Ocean monsoon to be followed by a

72 passageway through the Hormuz straights into the southern coast of Iran (Fig. 1), and a

73 northern path via the Nile river and the Sinai Peninsula.

74 During the Middle Pleistocene both land and sea bridges were potential dispersal

75 routes for hominins (Derricourt, 2006). However, the available archaeological evidence 
76 was retrieved only from the Levant with a few indications from the southern route

77 (Amirkhanov, 1991). During the Late Pliocene and Early Pleistocene there is no evidence

78 for a land bridge over the Bab el Mandeb straits. Indeed, during this time period,

79 dispersals of most animal and plants seem to have been limited to the terrestrial Northern

80 corridor of the Levant.

81 It is well-known that dispersals of early Homo ergaster/etectus from Africa across

82 Eurasia during the Early and Middle Pleistocene are interpolated from isolated

83 archaeological and fossil sites (e.g., Gabunia and Vekua, 1995; Larick and Ciochon,

84 1996; Bar-Yosef, 1998a; Potts, 1998; Arribas and Palmqvist, 1999; Bar-Yosef and

85 Belfer-Cohen, 2001; Potts, 2002; Antón and Swisher, 2004; Martínez-Navarro, 2004;

86 Lordkipanidze et al., 2007). The reasons for these long-range migrations, whether in a

87 form of "leap frog" expansions or gradual diffusion, are formulated as plausible

88 hypotheses, open to alternative interpretations. Moreover, the advantages for leaving

89 Africa are not easily testable (e.g., Bar-Yosef and Belfer-Cohen, 2001). One may use the

90 biogeographic ranges outside Africa, from the Iberian peninsula to East and Southeast

91 Asia, occupied by early hominins, to calculate the rate of movements and the chance for

92 long term survival of early mobile hunter-gatherers. Currently it seems that it took ca. 0.5

93 Ma to reach Western Europe by ca. 1.3 Ma (Agustí et al., 2000) and much less time to get

94 to ca. 1.66-1.7 Ma to East and Southeast Asia (Zhu et al., 2003; Antón and Swisher,

95 2004). One of the major questions is how African species adapted to the ecological

96 variability in Eurasia and the role the 'culture', as recorded in the stone tools, assisted (or

97 not) in the survival of lineages in the new territories. 
For the purpose of making the most parsimonious explanations about hominin

99 adaptations, and indicating where and when continuity is interrupted, probably by the

100 demise of some groups, we provide a brief review of current climatic and vegetation

101 conditions, a survey of the main Lower Paleolithic sites, followed by a summary of the

102 vegetation and faunal records as a basis for environmental reconstruction and long

103 distance correlations with known climatic events, and evaluation of hominin dispersals

104 through this region.

105

\section{Current Climatic Conditions}

107 The dominant physiographic feature of southwestern Asia is the combination of

108 mountains, plateaus, alluvial plains and desert landscapes including oases. The Anatolia

109 plateau is surrounded by mountains ranges in the north and the south where the Taurus

110 Mountains arching eastward into the Zagros Mountains. The Levant, along the eastern

111 Mediterranean coast has several parallel features. The narrow coastal plain in the north

112 widens in the south, the mountain ranges create the main watershed of this sub-region,

113 the Anuq-Beqa'a-Jordan Rift Valley stretches from north to south, and the Trans-

114 Jordanian or Syro-Arabia desert plateau descends eastward and southward. The

115 Euphrates and the Tigris rivers and their tributaries cross the Mesopotamian plain, which

116 is bordered by the Zagros Mountains and the Iranian plateau. The latter was and is mainly

117 desert strewn by oases.

118 Today's climate of the region is dominated by cold winters with the precipitation

119 brought by the westerlies. Snow falls only in the higher mountains, and in particular in

120 eastern Turkey and the northwestern Zagros. Summers are hot and dry. There is a wide 
121 range of variation across the region. Thus, winter temperatures are milder in the coastal

122 belts and more sever inland or at higher elevations and precipitation is effected by

123 distance from the Mediterranean Sea and the local sub-regional altitude.

124 The East Mediterranean region is located between the more temperate European

125 climatic zone in the north and the hyper arid regions of the Saharo-Arabian desert belt in

126 the south. Since the synoptic hydrological conditions may affect the entire southwestern

127 Asia, the question is whether and how warm to cold and humid to dry oscillations

128 affected the Levant since the Early Pleistocene (Frumkin and Stein, 2004).

129 Models of Pleistocene climates attempted to explain the paleoclimatic record of

130 the Levant. Earlier Butzer (1958) suggested a high correlation between the local

131 intensification of the westerly circulation of the Mediterranean during glacial periods and

132 the deep Cyprus Lows that would explain the increase in rainfall during glacial times.

133 Similar views were expressed by others (e.g., Horowitz, 1979). Recently, the extent the

134 increase of annual precipitation during North Hemispheric glaciations affected the

135 Levant, and whether it extended into the currently dry desert belt in the south has been a 136 topic of debate (Enzel et al., 2008 and references therein).

137 The climatic conditions and physiographic conditions determined the distribution

138 of the phytogeographic belts (Zohary, 1973; Danin, 1988), and the most frequently

139 encountered mammals in each region (e.g., Harrison and Bates, 1991; Harrison, 1972):

1401 . The Pontic province - the ‘Euro-Siberian' region corresponds to the Palearctic

141 deciduous and coniferous forests. It stretches from the southern edge of the Black Sea in

142 northern Turkey as well as relict enclaves in south in the Anti-Taurus Mountains, the

143 Syrian Amanus range and northern Lebanon. Part of the Pontic includes the Hyrcanian 
144 province of the coastal mountains of the southern Caspian Sea that descends into Iraqi-

145 Kurdistan and northern Syria. It included deciduous species of maple (Acer), birch

146 (Bitula), hazelnut (Corylus), beech (Fagus), ash (Fraximus), lime (Tilia) and elm (Ulmus)

147 that have a clear Arcto-Tertiary origin. Other evergreen species that occur in southern

148 Europe are present such as the boxwood (Buxus sempervirens), holly (Ilex aquifolium)

149 and yew (Taxus baccata).

150 2. Irano-Turanian province - covers the sub-regions of the Anatolian plateau, the

151 Syrian Desert, the Iranian plateau, and stretches into central Asia and the Gobi Desert.

152 The climate here is dominated by extremely cold winters and very hot summers with little

153 to no rain fall in the winter. It is dominated by dwarf scrubland and steppes vegetation.

154 3. The Saharo-Arabian province stretches south of the Mediterranean basin and

155 extends from Mauritania to the Red Sea incorporating the Sahara desert. This vegetation

156 is open xeromoprhic dwarf scrubland and desert plant associations.

157 4. The Mediterranean province spreads around the Mediterranean Sea and

158 includes a combination of maquis and forests dominated by oak (Quercus), Olive (Olea)

159 and almonds (Amgydalus communis).

160 5. The Sudano-Zambesian province is confined to the Jordan Valley and preserves

161 relicts of typical African subtropical savanna species such as the acacias.

162 Southwestern Asia was frequented by fauna from three biogeographic provinces:

163 Palaearctic, Oriental and Ethiopian in different proportions. Here we include a

164 description of extant fauna, all species dating to the early Holocene that predates the

165 effects of agriculture, horticulture and hunting. Thus most of the data comes from

166 archaeological excavations. 
168 coherent faunal community (Harrison and Bate, 1992). Two main regions can be

169 observed: The first includes the Mediterranean, Pontic and Iranian plateau provinces with

170 Palaeartic taxa, and the second includes the mesic Mediterranean, Arabian provinces with

171 Ethiopian elements. Taxa common to all regions include Hyaena hyaena, Felis silvestris,

172 Felis chaus, Panthera pardus, Acinonys jubatus, Lepus capensis, Hystrix indica, Rattus

173 rattus, Rattus norvegicus, Mus macedonicus. Palaearctic fauna which are found in the

174 Mesic regions of the Mediterranean, the Pontic and much of the Iranian plateau include

175 Dama mesopotamica, Capreolus capreolus, Cervus elaphus, Sus scrofa, Canis aureus,

176 Canis lupus, Vulpes vulpes, Panthera pardus, Ursus arctos, Martes foina, Vormela

177 peregusna, Mustela nivalis, Meles meles, Lutra lutra, Sciurus anomalus, Spalax

178 leucodon, Apodemus mystacinus, Apodemus sylvaticus, Cricetulus migratorius, Meriones

179 tristrami and Microtus guentheri. The Ethiopian taxa unique to the Arabian region are

180 Vulpes rueppellii, Vulpes cana and Vulpes zerda, Mellivora capensis, Genetta felina,

181 Felis margarita, Caracal caracal, Procavia capensis, Acomys cahirinus, Eliomys

182 melanurus, Gerbillus nanus, Gerbillus dayurus, Sekeetamys calurus, and Psammomys

183 obesus.

184 Nonetheless, while some genera are common throughout the entire region, the

185 species within each genus differ across the provinces. Thus, the unique species that

186 appear in each province give its unique affinities. For example, the caprine in the

187 Caucasus is Capra caucasica while the dominant Capra is the Iranian plateau is Capra

188 aegagrus and in the Mediterranean and Arabia is Capra ibex. The gazelle in the semi arid 189 regions of the Mediterranean is Gazella gazelle, in Arabia it is Gazella dorcas and in the 
190 Iranian plateau is Gazella subgotarossa. Furthermore, other species are unique to each

191 region. For example, species unique to the Pontic region are Lynx Lynx, Apodemus

192 flavicollis, and Mesocricetus auratus. Species unique to the Iranian plateau are the Ovis

193 ammon, Allactaga euphratica, Dryomys nitedula, Calomyscus bailwardi, Meriones

194 persicus and Ellobius fuscocapllius. Species unique to Arabia are Oryx leucoryx,

195 Tragelaphus imbris, Jaculus jaculus, Arvicanthis niloticus and Gerbillus gerbillus.

196 However, it is most important to remember that the home ranges of the species is

197 fluid rather than static, and are constantly changing dependant on climatic and

198 environmental changes and inter and intra species competition. Therefore, the presence-

199 absence of faunal elements correspond to the vegetation conditions, and disperse when

200 resources diminish during worsening climatic conditions that could also result in

201 extinction (Bennett, 1997). Thus in the following sections, we will discuss the changes in

202 the distribution of botanical and faunal compositions across the Early and Middle

203 Pleistocene in relation to the biogeographic provinces of southwestern Asia.

\section{Lower and Middle Pleistocene sites in Southwestern Asia}

The series of sites briefly described below form the isolated windows we have in

207 southwestern Asia into this long period of the Early and Middle Pleistocene. In the

208 absence of radiometric dating and/or paleomagnetic information the ages of several of the

209 localities rely on faunal correlations within the region including long distance

210 comparisons with European sites. Indeed, most of the Pleistocene data was acquired

211 through archaeological excavations while the number of assemblages derived from

212 natural accumulations is limited to a few Pliocene sites in the Caucasus region such as 
213 Kvabebi (Vekua and Lordkipadinze, 2008; Agustí et al., 2009b) and Bethlehem in the

214 Levant (see below).

215 There are special localities in the Levant that were thought to provide evidence

216 for early presence of hominins, but a close examination do not stand up to the

217 geochronological criteria. The mammalian fauna of Bethlehem is the oldest Plio-

218 Pleistocene assemblage known from the Levant. This was an animal bone accumulation

219 incorporated in a deposit of flint fragments and clay discovered when a local farmer was

220 digging a well (Gardner and Bate, 1937). The small collection of flints was originally

221 thought to include human artifacts but they have since been shown to be natural (Hooijer,

222 1958; Clark, 1961).

223 Another claim for an Early Pleistocene site named Yiron where core and flakes

224 have been retrieved from the gravels in a major crevice. Unfortunately the Yiron basalt

225 on the plateau did not cover this location and thus the date of the lava flow of $2.4 \mathrm{Ma}$

226 (Ronen et al., 1980; Ronen, 1991a), is unrelated to the human made lithics.

227 The 'Erq el Ahmar Formation (Horowitz, 1979) is located about $14 \mathrm{~km}$ south of

228 the Sea of Galilee, in the Jordan Valley and acumulated prior to the 'Ubeidiya Formation.

229 The polarity sequence is correlated with late Gauss and early Matuyuma chrons, within

230 which the Olduvai subchron was identified (Ron and Levi, 2001). Unfortunately the

231 artifacts mentioned in the different papers were found on the surface, except for a few

232 retrieved from a fluvial conglomerate of an unknown stratigraphic position (Tchernov,

233 1995). Hence, the attribution of these to the Olduvai subchron is only tentative and

234 cannot serve as a well-established evidence for hominin presence prior to Dmanisi (Bar-

235 Yosef, 1998a). 
The subsequent analysis of faunal turnovers in the Levant and the Caucasian

237 region is reported in relation to the cultural definitions, and supplemented by the

238 information from dated archaeological contexts (Table 1). It is followed by information

239 from the more poorly known regions of Anatolia, the Iranian plateau and the Arabian

240 Peninsula; For the sake of clarity, we briefly present the major sites that contain

241 archaeological remains and their cultural attributions in the Caucasian and the Levant

242 regions according to their accepted chronology and regardless of their geographic

243 location (Fig. 1). Numerous prehistoric occurrences were assigned to the Early and

244 Middle Pleistocene that did not yield fossil bones or datable substances or deposits

245 amenable to paleomagnetic readings. On morphological grounds the collected or

246 excavated artifacts were attributed to the Acheulian sequence such as the Early Acheulian

247 occurrences at Nahal Zihor in the Negev (Ginat et al., 2003) or the Late Acheulian in

248 Ma'ayan Baruch in the Upper Jordan Valley. In summarizing the archaeological

249 information we do not describe the faunal and floral remains found in each site in this

250 section, as they will be discussed in length in the following one. The condensed

251 information will allow us to demonstrate below that the assumptions concerning

252 continuous hominin dispersals into Eurasia relies on a series of speculations and that the

253 proposed timing of prehistoric migration is not well tied with the transitions among the

254 faunal assemblages.

255

$256 \quad$ Dmanisi

257 The site of Dmanisi is located on a basaltic block bordered by two tributaries of 258 the larger Kura River. The prehistoric deposits were target for systematic excavations 
259 (Vekua, 1987; Dzaparidze et al., 1989; Gabunia and Vekua, 1990, 1995; Liubin and

260 Bosinski, 1995;Liubin and Bosinski, 1995; Lordkipanidze et al., 2007; Jöris, 2008;

261 Rightmire et al., 2006). The geoarchaeological study concluded that entire sequence at

262 Dmanisi could be dated to the Olduvai subchron and immediately after as shown by the

263 normal polarity of the lower lava flow $(1.8 \pm 0.1 \mathrm{Ma})$ and the infillings of the upper

264 deposit that date to 1.77 Ma. Several human skulls and postcranial bones are attributed to

265 Homo erectus/ergaster (Gabunia and Vekua, 1995; Rightmire et al., 2006; Lordkipanidze

266 et al., 2007). The lithics of Dmanisi are identified as core and flake industry sometimes

267 called "pre-Oldowan" or Mode 1 (de Lumley et al., 2005; Jöris, 2008). The Dmanisi core

268 and flake industry marks the presence of hominins that did not practice the production of

269 handaxes (bifaces). It indicates that handaxes were not a necessity for the colonization of

270 Eurasia. The Dmanisi faunal assemblage is earlier than the faunas of Sénèze and Le

271 Coupet, and thus also earlier than 'Ubeidiya (Tchernov, 1987).

272

273 'Ubeidiya

274 'Ubeidiya is situated on the edge of the western escarpment of the Jordan Rift

275 Valley and its geological structure was uncovered through a series of excavations

276 (already reported in details) an anticline with several undulations disturbed by a few

277 faults (Bar-Yosef and Tchernov, 1972; Bar-Yosef and Goren-Inbar, 1993). The exposed

278 tilted layers were numbered from those observed as the earliest to the latest over a total

279 thickness of $154 \mathrm{~m}$. The sequence was subdivided into four cycles: two mostly limnic (Li

280 and $\mathrm{Lu}$ ) and two essentially terrestrial ( $\mathrm{Fi}$ and $\mathrm{Fu})$.

281 The raw materials used for manufacturing artifacts were lava (basalt), flint, and 
282 limestone. The basalt nodules occurred as pebbles, cobbles, boulders, and scree

283 components; the limestone was available as much more sparse cobbles within the beach

284 and wadi deposits; and the flint is found in the same environments as small pebbles and

285 cobbles. The 'Ubeidiya hominins employed each type of rock to shape a different type of

286 object (Bar-Yosef and Goren-Inbar, 1993). Core-choppers and light-duty tools were made

287 of flint, spheroids mainly of limestone, and the handaxe group from basalt, with a few of

288 flint and limestone. There is a direct correlation between the size of the tool-category and

289 the type of raw material. Although basalt is the most common rock and found in every

290 lithological facies at 'Ubeidiya the most abundant object is the core-chopper, which is

291 made of flint and its detached pieces (flakes). It seems that the lithic assemblages from

292 the lower most layers in the sequence (K/III-12, III-20-22, II-23-24) contain an

293 abundance of core-choppers, polyhedrons and spheroids but lack bifaces, except for one

294 trihedral. The samples are large enough to suggest that they may indicate the presence of

295 an early group of hominins that did not produce bifaces. The overlying assemblages

296 contain bifaces in varying frequencies and can be called Early Acheulian (Bar-Yosef and

297 Goren-Inbar, 1993). As the presence or absence of bifaces is taken to designate different

298 groups of hominins one may speculate that as in Dmanisi, the first hominins to arrive at

299 'Ubeidiya, were not the bearers of the Acheulian.

300 Among the so-called formal categories the frequencies of bifaces are abundant in

301 gravelly layer K-30 although the underlying layer K-29 of the same wadi fill produced

302 very few bifaces. It seems that certain activities were carried in the hilly-forested areas

303 from which the more abraded assemblage of K-30 was derived. The almost total

304 disappearance of bifaces in the later assemblages at 'Ubeidiya is noticeable and as yet 
unexplained.

306 Estimated dates for the fossil-bearing strata of the 'Ubeidiya Formation are

307 between ca. 1.6 - 1.2 Ma. Paleomagnetic analysis of the 'Ubeidiya Formation indicated a

308 reversed polarity suggesting that it predates the Brunhes - Matuyama reversal (Opdyke et

309 al., 1983; Braun et al., 1991; Verosub and Tchernov, 1991). Two short, normal

310 paleomagnetic episodes have been found in the Fi member layers II-33 and II 23-24.

311 Layer II-33 has been assigned to the Cobb Mt. (1.215 - 1.190 Ma) and layer II 23-24 has

312 been assigned to the Gilsa (1.575-1.567 Ma) (Sagi, 2005). This correlation fits well with

313 an ESR date of ca. 1.2 Ma for the stratum I 26 which immediately overlays stratum II 33

314 (Rink et al., 2007).

315 The dating of these short polarity events was also corroborated by local faunal

316 turnovers (Belmaker, 2009). The 'Ubeidiya fauna (Table 1) can be assigned to a local

317 mammalian fauna biozone older than the assemblages of Bitzat Ruhama, Evron-Quarry

318 and Latamne (Belmaker, 2009). All these sites have been dated to ca. 1.0-1.2 Ma

319 suggesting that the 'Ubeidiya normal polarity events in strata II 23-24 and II-33 should

320 both predate the Jaramillo (0.99-1.07 Ma). Further corroboration by long-range

321 biochronological correlations indicates that the large mammalian assemblage of

322 'Ubeidiya is similar to the Farneta faunal unit (the sites of Selvella and Pietrafitta, Italy)

323 (Belmaker, 2006; Martínez-Navarro et al., 2009), which has been dated to ca. 1.6-1.2 Ma

324 (Caloi and Palombo, 1997 and references therein). Employing similar approach of long

325 distance comparisons to the lithics of 'Ubeidiya suggests that the assemblages are similar

326 to those from upper Bed II at Olduvai dated to ca. 1.53-1.27 Ma (Bar-Yosef and Goren-

327 Inbar, 1993; Cerling and Hay, 1986). 


\section{Evron-Quarry}

330 The excavations at Evron-Quarry, located in the coastal plain of the Western

331 Galilee, exposed a sequence of alternating deposits of sandstone (kurkar), sometimes up

332 to three meters thick, and red-brown loams (hamra), either as isolated lenses or layers up

333 to about one to four m thick (Ronen, 1991b). The layer that contained the Acheulian

334 industry had two distinct horizons of calcareous concretions, occasional artifacts, and

335 sandy clay lenses with pebbles (two to three meter thick) separated from the dark brown-

336 black clay (two m thick) that contained Late Acheulian artifacts and a few animal bones.

337 The artifacts within the archaeological horizon had a vertical distribution of $15-25 \mathrm{~cm}$

338 deep, a phenomenon interpreted as the result of repeated occupations.

339 The archaeological assemblage contained small pebbles of quartz, limestone, and

340 flint, with most of the artifacts made of the latter raw material. No bifaces were found in

341 the excavated areas probably due to their small surface but earlier searches in the quarry

342 dumps recovered twenty handaxes. These are of large size (140-220 $\mathrm{mm}$ in length) and

343 demonstrate a relatively crude workmanship that resembles that of the Latamne site

344 (Ronen, 1991b). Large cobbles from which the bifaces were made were recovered

345 together with a group of hard calcite geodes, the heaviest of which was $580 \mathrm{~g}$, were

346 brought to the site by the occupants from about $5 \mathrm{~km}$ away.

347 Chronologically, the context of Evron-Quarry is assigned to a post-'Ubeidiya age,

348 and is perhaps contemporaneous with the Latamne site in Syria (ca 1.0-0.8 Ma).

349 Paleomagnetic and ESR studies of the archaeological bearing strata have suggested a date 350 ca. 1.0 Ma (Porat and Ronen, 2002; Ron et al., 2003). 
353 The site of Bizat Ruhama is situated in the southern coastal plain and the

354 archaeological horizon is incorporated in a paludine deposit (Ronen et al., 1998; Zaidner,

355 2003a, b; Zaidner et al., 2003). The retrieved rich lithic industry, generally made of small

356 flint pebbles, falls within the category of "core and flake" assemblage with intensively

357 retouched flakes (small borers, notches and denticulates, etc.) No bifaces were found.

358 Paleomagnetic information and TL dates places the site at 0.99 to $0.85 \mathrm{Ma}$ (Laukhin et

359 al., 2001; Ron and Gvirtzman, 2001).

\section{Latamne}

The site of Latamne was excavated by D. Clark (1967) and additional fieldwork

363 was conducted by Sanlaville and his associates (1993). The archaeological horizon of

364 Latamne lay in the mid-sequence of the Latamne Formation. It contained the Latamne

365 “occupation floor," a silt layer only a few centimeters thick (up to $10 \mathrm{~cm}$ ) capped by

366 sandy-silty bedding with traces of rootlets. The sequence was interrupted by erosion and

367 was overlaid by a fluvial sandy deposit, capped by a lacustrine layer (Sanlaville et al.,

368 1993).

369 Geomorphological observations indicate that the archaeological horizon of

370 Latamne resulted from a low energy water flow responsible for the deposition of the

371 artifacts and their pattern of spatial distribution. About one-third of the total recorded

372 artifacts, made from local available flint, limestone and basalt, were slightly abraded or

373 fully abraded. Tool classes can be roughly divided into a collection of bifaces, light duty 
374 scrapers, heavy-duty tools, and a few limestone and basalt spheroids. Several handaxes

375 are trihedral picks similar to those found at 'Ubeidiya.

376 Water activity caused leaching of the sediments as well as diagenesis that

377 destroyed most of the bones. Most of the well-preserved identifiable bones were collected

378 from the gravels underneath the archaeological site (Hooijer, 1962; Guérin et al., 1993).

379 The entire assemblage reflect a great similarity between the faunas from Latamne and

380 'Ubeidiya. Originally, the date of the site was estimated as ca. 0.7 Ma based on faunal

381 correlations (Guérin et al., 1993) but the presence of the arvicolid Lagurodon arankae

382 and typo-technological affinities of the lithic assemblage suggest a date ca. 1.0 Ma

383 (Tchernov, 1994). However, a single TL date of $560 \mathrm{ka}$ for the Latamne Formation led to

384 the conclusion that the site is 700-500 ka years old (Sanlaville, 1988; Sanlaville et al.,

385 1993) which seem untenable.

Dursunlu

The quarry of Dursunlu is $75 \mathrm{~km}$ northwest of Konya, western Turkey. It

389 comprises Early Pleistocene lucustrine limestones, marls and clay with lignites.

390 Paleomagnetic analysis has suggested a reverse polarity punctuated by three episodes of

391 normal polarity, consistent with an Early Pleistocene age. A more detailed analysis of the

392 drilled cores suggested that the artifacts were derived from two layers between the

393 Jaramillo and MBB, i.e., 0.99 and $0.78 \mathrm{Ma}$ (Güleç et al., 2009). Most of the small lithic

394 assemblage was made of quartz with rare pieces of flint and an igneous rock. The

395 assemblage falls under the category of core and flake industry and provides a unique

396 point in the presence of early hominins in Anatolia. 


\section{Gesher Benot Ya'aqov}

399 The site of Gesher Benot Ya'aqov (GBY) lies in the Jordan Valley, at the eastern

400 edge of a vast, basalt-covered area. The excavations in the 1930s by M. Stekelis, and

401 recently by Goren-Inbar and her associates (Goren-Inbar et al., 1991, 1992a, b, 2000,

402 2004; Goren-Inbar and Saragusti, 1996; Alperson-Afil et al., 2007) provided an African-

403 type assemblage of cleavers and bifaces that is unlike any of the other known 200

404 Acheulian occurrences in southwestern Asia including both surface and excavated

405 occurrences (e.g., Hours, 1975, 1981; Bar-Yosef, 1987; Goren-Inbar, 1995; Liubin, 2002;

406 Taskiran, 1998). The nature of the deposits and the malacological assemblages,

407 dominated by Viviparus apameae, indicate that the archaeological assemblages

408 accumulated on the shores of an expanding lake that flooded the gorge (Horowitz, 1979;

409 Goren-Inbar et al., 1991, 1992a, b; Goren-Inbar and Saragusti, 1996; Feibel, 2004).

410 The complex stratigraphic sequence, first partially exposed by M. Stekelis (1960)

411 and more recently by systematic excavations conducted by N. Goren-Inbar (Goren-Inbar

412 et al., 2004; Feibel, 2004) contains early layers with Acheulian industry dominated by the

413 production of cleavers and bifaces from basalt, as well as flint and limestone objects.

414 Some of the cleavers were fabricated by the Kumbewa technique. Although lava flows

415 cover the area, on both sides of the parts of Jordan River and in particular the large area

416 of the Hauran-Golan no other Acheulian sites with basalt industry were located. On the

417 contrary, in most cases flint nodules derived from isolated limestone and chalky outcrops,

418 often of Eocene age, served as raw material for fabricating handaxes (e.g., Goren, 1979;

419 Goren-Inbar, 1985; Ohel, 1991). 
421 that accumulated above a lava flow with normal polarity. The lava flow, designated as the

422 Yarda Basalt, was first K/Ar dated to $0.68 \pm 0.12 \mathrm{Ma}$ (Horowitz, 1979) and later to

$4230.9 \pm 0.15 \mathrm{Ma}$ (Goren-Inbar et al., 1992a). However, the paleomagnetic sequence within

424 the excavated deposits demonstrated that the Matuyama Brunhes Boundary (MBB) was

425 located within the series of deposits and the accumulation of the entire sequence took

426 place during ca. 100,000 years (Feibel, 2004).

\section{Holon}

429 The site of Holon is embedded in marshy deposits overlying an abraded kurkar 430 ridge dated by Horowitz (1979) to around 500-400 ka. The site contained more than one 431 level (Chazan and Kolska-Horwitz, 2007). ESR and luminescence dating (Porat et al., 432 2002) suggested for the archaeological horizon an average date of ca 205 ka based on 433 ESR and TL dates and suggested that is comparable to the ESR readings from teeth from 434 Tabun layer E of Garrod's excavations (the Acheulo-Yabrudian industry). However, TL 435 dates of burnt flint pieces from Tabun E indicate an age older of $270 \mathrm{ka}$, considered as the 436 onset of the Mousterian (Mercier et al., 1995) dated also in other sites around 220-250

437 ka. Unfortunately the dates for Holon were retrieved from another geological exposure as 438 the area of the original site lies below a major factory.

439 The bifaces of Holon are mostly of pointed and rounded aspects; the flake 440 industry contains side scrapers, denticulates, and notches, along with cores and debitage 441 products This lithic assemblage has been attributed to the Late Acheulean (Chazan and 442 Kolska-Horwitz, 2007) and if the dates are accepted it would mean that either the Holon 
443 Acheulian was contemporary with the early Mousterian, which is untenable, or that there

444 is a systematic difference between the luminescence dates of quartz grains that were

445 retrieved from another location although near the location of the original excavation.

\section{Qesem}

Qesem Cave is located $12 \mathrm{~km}$ east of Tel Aviv, Israel. Excavation in the cave

449 revealed several meters of deposits with abundant lithic and faunal assemblages and

450 plenty of evidence for systematic use of fire (Karkans et al., 2007). Uranium series dates

451 have suggested an age bracket of $0.4-0.2 \mathrm{Ma}$ (Barkai et al., 2003). The rich lithic

452 assemblages, dominated by the production of blades, were assigned to the Amudian

453 culture (Gopher et al., 2005; Barkai et al., 2006; Lemorini et al., 2006).

\section{Revadim}

456 Revadim Quarry is located on the southern coastal plain of Israel, north of

457 Kibbutz Revadim. Paleomagnetic dates suggest a normal polarity indicating an age

458 younger than 0.78 Ma. OSL dates suggest a minimum age bracket of 0.3-0.2 Ma.

459 (Gvirtzman et al., 1999; Marder et al., 1999). The lithic assemblage at the site suggests a

460 high frequency of flake tools and the presence of handaxes. The typo-technological

461 characteristics of the bifacial tools have suggested that it may be attributed to the Late

462 Acheulean culture (Marder et al., 1999, 2006). 
The site of Oumm Zinat is situated 500 m east of Kibbutz Evron and was first

466 excavated by Prof. Stekelis in 1950. Subsequent excavations by Gilead and Ronen in

4671977 revealed a small to medium size assemblage dominated by hand axes

468 contemporaneous with Late Acheulean such as Oum Qatafa D1 and Tabun E/F (Kolska-

469 Horwitz and Tchernov, 1989)

470

\section{Tabun E}

Tabun Cave in location on the Southwest flanks of Mount Carmel, Israel on the

473 banks of Wadi el Mughara (Nahal Me'arot). The excavation of the cave began in 1930's

474 under Bate and Garrod and continued with Jelinek (1970-1972) and recently A. Ronen

475 since the 1990's. Layer E consists of slightly abraded flint over an area of 1.0X1.3 m.

476 The lithic assemblage was characterized as Late Acheulean (Garrod and Bate, 1937).

477 The TL dates for Tabun Ed to D suggested that they were deposited during MOIS

4789 through 8 (Mercier et al., 1995), more recent dates by Mercier and colleagues (2000)

479 suggest that Tabun $\mathrm{F}$ and $\mathrm{E}$ were deposited during MOIS 9 between $350 \pm 30$ and $330 \pm 30$

480 ka. However, ESR dates for Tabun E by Grün et al., (1991) and Grün and Stinger (2000)

481 suggested a date of only $200 \mathrm{ka}$.

482

483

Oumm Qatafa

Oumm Qatafa is situated on the left bank of Wadi Khareteitun in the Judean

485 Desert, ca. $15 \mathrm{~km}$ west of the Dead Sea. The site was excavated by R. Neuville between

486 1928-1949 (Neuville, 1951) where he identified a sequence which spans the chacolithic 
487 through the Lower Paleolithic. The Upper Acheulian level in D2 is characterized by

488 broad, ovate discoidal and cordiform bificaces. Recent ESR dates obtained from level

489 D2 indicate an upper date of $213 \pm 26 \mathrm{ka}$ and thus an end for the late Lower Paleolithic

490 (Porat et al., 2002).

\section{Early and Late Acheulian in the Levant}

Surveys along the Levantine coast located a few occurrences that appear to be of

494 Early Pleistocene age although dating, in most cases, is rather tenuous due to lack of

495 datable substances. Shorelines were dated on the basis of their elevation above sea level,

496 while the known relative ages of foraminifera and marine shell assemblages were also

497 incorporated into these figures along the western mountainous range along the Levantine

498 coast, a few artifacts were found on terraces as high as $120 \mathrm{~m}$ above sea level. We

499 therefore choose to summarize those sites where systematic excavations or surveys were

500 conducted and their dates depend of the geological stratigraphy and its suggested

501 correlation with sea level chronology. Here we add some brief information about the

502 main occurrences, and for a full survey see the available summaries (e.g., Hours 1975,

503 1981; Muhesen, 1985, 1993; Sanlaville et al., 1993; Bar-Yosef, 1998a).

504 One of the distinctive sites is Kefar Menachem, situated in the interior part of the

505 coastal plain and was excavated twice (Gilead and Israel, 1975; Barzilai, 2006). The

506 lithic industry is embedded in red loam of an Early Pleistocene age (Horovitz, 1979). The

507 lithic assemblages of both excavated areas are comprised of numerous core and flake

508 products, a few flake-tools (classified as end-scrapers, side scrapers, burins, notches, and

509 denticulates). The use of direct hard hammer percussion is dominant. To date, the rare 
510 bifaces have been found only on the surface and their attribution to the excavated

511 collections is doubtful. These bifaces are described as irregular ovates, picks, long

512 lanceolates, and backed bifaces (Gilead and Israel, 1975) who tentatively related this

513 surface assemblage to the Early Acheulian.

514 Most of what is known from the areas of Lebanon and Syria was obtained through

515 the study of the terraces of Nahr el Kebir, the Orontes, and the Middle Euphrates. The

516 majority of the collections were classified as Early and "Middle Acheulian" first on the

517 basis of stratigraphic grounds and later upon consideration of their typological

518 characteristics. Rare finds were retrieved and in several localities in the Beqa'a Valley.

519 Lithic studies of the so-called "Middle Acheulian" assemblages identified two

520 geographic facies. The sites along the coast, such as Berzine and Ouadi Aabet, contain

521 essentially amygdaloid and oval bifaces, while the inland sites (Joub Jannine II and

522 Latamne) have more lanceolates and trihedral picks, and along the Nizip river (Minzoni-

523 Déroche and Sanlaville, 1988), a tributary of the Euphrates in Turkey, recognized a

524 similar distribution of the "Middle Acheulian" artifacts.

525 The general technological tendency among the Achuelian sites is toward a greater

526 use of soft hammer percussion and the sporadic appearance of the Levallois technique

527 (Copeland and Hours, 1981). Typologically, the almost total disappearance of core-

528 choppers is noticeable. The cordiform and amygdaloid bifaces outnumber the ovates. The

529 length of the handaxes decreases in general, a tendency that was already noted by D.

530 Gilead (1970) for the southern Levantine samples.

531 The sites of Hummal and Nadaouiyeh I were discovered in El-Kowm basin

532 (Hours et al., 1983; Le Tensorer et al., 1993), and exposed several occupational horizons. 
533 Nadaouiyeh I comprised of an accumulation of alternating clayey layers and by sandy

534 layers near an artesian spring. The stratigraphy is a complex one, marked by slumping

535 and erosion. The systematic excavations demonstrated the presence of in situ Acheulian

536 assemblages. The bifaces, generally amygdaloid, were accompanied by a rich flake

537 industry in every one of the six tested layers. The presence of the Levallois technique was

538 noted in low frequencies. In addition, the both Hummal where a much longer depostional

539 sequence was revealed and Nadaouiyeh contain Yabrudian or Acheiulo-Yabrudian

540 capped by Hummalian (an early Mousterian industry) contexts (LeTensorer 2004).

541 Subdividing the Late (or Upper Acheulian) into phases or "facies" was and still is

542 not an easy task. On the basis of technological and morphological considerations Gilead

543 (1970) subdivided the Late Acheulian into several groups as follows:

544 A. The Ma'ayan Barukh group (MB), mostly from open-air sites, is characterized

545 by the dominance of the cordiform aspect (including amygdaloids, cordiforms and

546 subtriangulars) with fewer ovate and a few pointed bifaces and rare cleavers. The

547 assemblage from the excavations of Umm Qatafa D2 is included in this group.

548 B. The Evron-Kissufim group (EK) is, on the basis of stratigraphic evidence,

549 later than the MB group. It contains a richer flake tool component, up to $30-60 \%$, with

550 clear evidence for the manipulation of the Levallois technique. The bifaces show a

551 decrease in rounded aspects (ovates and discoids) and a slight increase in the pointed

552 forms.

553 C. The Sahel el-Khoussin-Yiron group (SY) are those assemblages mostly surface

554 collected in the hilly areas and flanks. The bifaces are somewhat cruder than those of the

555 other groups with an occasional dominance of the rounded aspect over the cordiform 
556 aspect (Yiron, Beith Uziel, Baqaa-Rafaim etc.). As in the EK group, the Levallois

557 technique was practiced in some sites. It is worth noting that despite the hilly distribution,

558 these assemblages are not present in the three caves where Late Acheulian layers were

559 uncovered (Tabun F, Abu Sif, Umm Qatafa D).

560 The frequency of refinement index (thickness/breadth $\mathrm{x} 100$ ) demonstrates the

561 differences among the sites. The same is probably true when the mean length among Late

562 Acheulian sites is considered. Wherever large cobbles were available, there was a

563 tendency towards larger bifaces. However, a general tendency for decrease in biface

564 length could indicate increasing efficiency of resharpening (perhaps longer curation?)

565 during the Late Acheulian.

566 The flake industry of most of the Late Acheulian occurrences is not very well

567 known. In some places, the number of flakes cannot account for their manufacture. For

568 instance, the thousands of bifaces found in Ma'ayan Barukh may have been produced in

569 an area further north near the Litani River. The flakes collected from the same surface

570 clusters could indicate some resharpening (although small flakes and chips are not easy to

571 retrieve in the deep red soil of these hills). It seems that the concentration of bifaces near

572 the Hula Lake shores on the interfluves of freshwater creeks may represent repeated

573 butchering activities in a pristine environment.

574 A unique Late Acheulian site, embedded between a lava flow dated to $233 \pm 3 \mathrm{ka}$

575 and an older lava flow dated to $800 \mathrm{ka}$, was excavated on the edge of the crater lake

576 known as Berekhat Ram on the Golan plateau (Goren-Inbar, 1985). The rich assemblage

577 contains several thousands of artifacts, mostly in mint condition, with about four hundred

578 of retouched pieces including eight small bifaces. The makers of the industry employed 
579 the Levallois centripetal (radial) technique. A special find is a human figurine (Goren-

580 Inbar, 1986) that recently received much attention in the debate concerning the capacities

581 of Archaic Homo sapiens or late Homo erectus (e.g., Marshack, 1997; D’Errico, 2000).

582 The actual date of the site is unknown but given the current TL dates of the Acheulo-

583 Yabrudian, it should be placed during the time span of 350-450 ka.

$584 \quad$ In general, Late Acheulian sites can be found across the southwestern Asia in

585 every environment including the coastal plain, hilly areas, inter-montane valleys, and

586 oases and in desert landscapes. The best example to date from an oasis situation is the

587 series of Late Acheulian assemblages which is characterized by high frequencies of

588 bifacial cleavers, uncovered in the Azraq basin (Copeland and Hours, 1989; Rollefson,

589 1997). Among these, the sounding at Lion Spring provided stratified lithic assemblages

590 that are characterized by ovate, amygdaloid, and cordiform bifaces, with a rich flake

591 industry. In the absence of precise dating and on the basis of comparisons with the

592 occupations in other location it seems that some Late Acheulian occupations should be

593 correlated with periods of wetter conditions during the time span of ca. 600-400/350 ka.

The Acheulo-Yabrudian

596 The Acheulo-Yabrudian, was renamed as the Mugharan Tradition by Jelinek

597 (1981, 1982a, b), and has a definite geographic distribution from the Taurus foothills to

598 the central Levant (Bar-Yosef, 1998b). It is generally dated to 400/350- 250/220 Ka, and

599 is found stratigraphically always under the Early Mousterian (e.g., Tabun, Hayonim,

600 Misliyeh caves; Garrod and Bate, 1937; Weinstein-Evron et al., 2003). We stress that in

601 spite of intensive surveys, none of the typical artifacts by which this entity is defined 
602 were found in the Negev and Sinai or in the desert region of southern Jordan. Three

603 facies that sometimes considered as independent industries were identified on the basis of

604 quantitative studies, as follows (Jelinek, 1982a, b; Copeland and Hours, 1983):

605 1. The Yabrudian facies contains numerous side-scrapers, often made on thick

606 flakes including canted ones, thus resulting in relatively high frequencies of Quina and

607 demi-Quina retouch with a few Late Paleolithic tools and rare blades. Although

608 typologically, Levallois-type products have sometimes been mentioned, the

609 reconstruction of operational sequences has not yielded a well-identified Levallois

610 method.

6112 . The Acheulian facies is considered by Jelinek (1982a, b) to consist of up to 15

612 percent bifaces, with numerous scrapers fashioned in the same manner (Quina type scalar

613 retouch) as the Yabrudian ones.

6143 . The Amudian facies is characterized by end scrapers, burins, backed knives,

615 and rare bifaces and was therefore originally called 'Pre-Aurignacian' in the sense of

616 being blade dominated. Not surprisingly, until the 1940s the term Aurignacian was used

617 to refer to all early Upper Paleolithic industries in Western Eurasia. The Amudian facies,

618 following the Tabun excavations, seems to be closer typologically to the Acheulian than

619 to the Yabrudian and contains evidence for limited practice of the Levallois technique

620 (Jelinek, 1982a, b). The "Pre-Aurignacian" in Yabrud I and Abri Zumoffen are richer in

621 "Upper Paleolithic" elements. The excavations at Qesem cave produced rich assemblages

622 of blades and platy of evidence for the use of fire (Gopher et al., 2005; Barkai et al.,

623 2006; Karkans et al., 2007) and a faunal assemblage dominated by Fallow deer (Stiner et

624 al., 2004). 


\section{The Lower Paleolithic of Iraq, Iran and the Caucasian region}

627 The vast geographic area summarized here is generally poorly known. The scant

628 evidence from Turkey on one end of the region and India on the other, including a few

629 recorded find spots from Iran (Smith, 1986) and from the Arabian Peninsula (Zarins et

630 al., 1979, 1980, 1982; Whalen et al., 1983, 1984; Abdul Nayeem, 1990), indicate that

631 bifaces can be found everywhere. The distribution toward the northern edges of the Near

632 East has implications for the reexamination of the "Movius line".

633 In Iraq, little is known beyond the site of Barda Balka, located in the Chemchemal

634 valley in Kurdistan, which was collected and excavated by Howe (Braidwood and Howe,

635 1960). This predominantly flake assemblage may be of Middle Paleolithic age. Iranian

636 finds are also few and are far apart. In Khorasan, on the edge of a dried-up lake, quartzite

637 and andesite core-choppers were collected (Ariai and Thibault, 1975/77). In the absence

638 of dates, the investigators related the assemblage to the Late Pliocene on typological

639 grounds. Isolated bifaces have been collected in various places in Iran (Smith, 1986). The

640 Ladizian industry in Baluchistan (Hume, 1976) to the east should be mentioned briefly. It

641 is defined on the basis of scatters of lithics on old river terraces and it is a core-chopper

642 industry with retouched pieces but no bifaces. Hume (1976) has proposed a late Middle

643 Pleistocene age for the Ladizian.

644 Early and Late Acheulian sites in Georgia were either surface collected or

645 excavated (Liubin and Bosinski, 1995; Liubin, 2002). Among the surface sites, some of

646 the interesting collections were done in Cikiani, near Paravani in southern Georgia, where

647 cleavers and handaxes were found (Kikodze, 1986). The bifaces were made of andesite 
648 but most of the cores were made of obsidian. Persati, another surface site, which is yet

649 unpublished, is located on top of a volcanic plateau that is apparently the continuation of

650 the Dzavacheti range in southern Georgia, about 2100m above sea level (Kikodze,

651 personal communication). The artifacts were found at the edge of lacustrine sediments,

652 dated to the Neogene. One of the find spots seems to be eroding from these lake deposits,

653 but radiometric dates are not available.

654 Acheulian industries were uncovered in four excavated caves: Azych, Kudaro I

655 and III, and Tsona. The lithic industry in Azych, located $800 \mathrm{~m}$ above sea level, is

656 subdivided on the basis of the observed stratigraphy into several phases of the Acheulian.

657 The earliest levels produced a few core-choppers but they are without clear attribution to

658 a prehistoric entity (Liubin and Boskinski, 1995; Liubin 2002). The richest assemblages

659 were uncovered in layers VI and V, including mainly Late Acheulian bifaces with distinct

660 use of the Levallois technique. In layer V, a fragment of a hominid mandible was found.

$661 \quad$ Kudaro I is situated $1600 \mathrm{~m}$ above sea level. Layer 5 contained Acheulian

662 artifacts made from local raw material. The entire assemblage is characterized by a high

663 frequency of retouched pieces including numerous side scrapers. Core-choppers and

664 bifaces, mostly of elongated shapes, assign this assemblage to the Late Acheulian. The

665 presence of flake cleavers was noted by the excavator. Three human teeth were also

666 found in this context. Dates suggest a range of 250-300 ka. TL readings indicate a

667 slightly earlier time, $360 \pm 90 \mathrm{Ka}$ and 350 $\pm 70 \mathrm{ka}$. However, a reversed paleomagnetic

668 situation identified in level 6 immediately below the Acheulian, with the fauna of several

669 Galerian elements, hints that the Acheulian in layer 5 is perhaps of an older age (Liubin

670 and Bosinski, 1995). 
672 bifaces and flake tools. A TL date of level 8 a was $560 \pm 112 \mathrm{ka}$, while layer 5 produced

673 dates of $252 \pm 51 \mathrm{ka}$ and $245 \pm 49 \mathrm{ka}$ (Liubin, 2002).

674 Tsona Cave, at an altitude of $2150 \mathrm{~m}$ above sea level, and just about 5-6 km south

675 of Kudaro, is a very large cave. The Acheulian industries were derived from layers 6-7a.

676 Preliminary reports indicate that the lower assemblages (layer 7) that were originally

677 considered as Early Acheulian produced only a small sample. The assemblage of layer 6

678 assigned to the Late Acheulian contained about 100 artifacts, including 29 bifaces made

679 from local raw material, mostly retrieved in the form of pebbles. The chronological

680 position of this Acheulian is not well-known, however it seems that this cave, like others

681 at high altitudes, could have been occupied only during interglacial times and in most

682 cases were possibly only seasonal hunting camps. At least two other cave sites on the

683 northern flanks of the Caucasus are known to contain Late Acheulian remains.

684 In sum, the distribution of the Acheulian industries in Western Asia is essentially

685 limited mainly to the Levant with decreasing abundance in the Caucasian region and 686 eastern Anatolia. In spite of the paucity of information from Iran, as mentioned above,

687 there is no evidence for continued distribution of the Acheulian into India. Thus, the

688 "Movius Line," which distinguishes between the Acheulian and the non-biface industries, 689 separates Anatolia from Eastern Europe and the Iranian plateau and Baluchistan from the 690 Levant.

\section{Human remains}

693 While the lithic stratigraphy in the region is rather complete, the hominin remains 
694 are woefully underrepresented. The Lower Paleolithic sequence of Western Asia, apart

695 from Dmanisi, is very poor in human fossils. Dmanisi, as mentioned above, contained

696 several skulls and postcranial bones, demonstrating a large range of morphological

697 variability (Gabunia and Vekua, 1995; Braüer and Schultz, 1996; Gabunia et al., 2000a;

698 Gabunia et al., 2002; Lordkipanidze et al., 2007; Rightmire et al., 2006).

699 The available human remains from this long period are scanty, and a few are

700 surface finds. The extensive excavations at 'Ubeidiya (1959-1999) have revealed

701 numerous lithics which attest to hominid presence in the Southern Levant during the

702 Early Pleistocene. Several cranial fragments (UB 1703, 1704, 1705 and 1706), an incisor

703 (UB 1700) and a molar (UB 1701) have been assigned to Homo indet. (Tobias, 1966a,

704 1966b) and as Homo cf. erectus (Tchernov and Volokita, 1986). Belmaker et al., (2002)

705 described a new right lateral hominid incisor (UB 335) from stratum I-26a and which was

706 assigns to Homo cf. eragster. However, the antiquity of the previous finds has been

707 contested, and UB 335 is the only one that can be securely assigned to the Early

708 Pleistocene deposits.

709 Two broken femora from GBY (Geraads and Tchernov, 1983), attributed to

710 Homo erectus, were identified in the collections of animal bones made at the site when

711 the deepening of the Jordan River channel took place.

712 A broken femur was uncovered in Tabun cave layer E (McCown and Keith, 1939)

713 within the Acheulo-Yabrudian assemblage. It thus occupies the same stratigraphic and

714 chronological position as the fragmentary skull from Zuttiyeh (Gisis and Bar-Yosef,

715 1974). The latter is considered as an example of an Archaic Homo sapiens

716 (Vandermeersch, 1995) and could have been one of the potential ancestors of the later 
717 Qafzeh-Skhul group. Recently, this fragmentary skull has been compared to the

718 Zhoukoudian human remains and interpreted as belonging to a generalized Middle

719 Pleistocene Asian population (Sohn and Wolpoff, 1993).

720 Only after MOIS 5 do hominin remains (both of Anatomically modern humans

721 and Neanderthals) become more common in the region and allow to fully discuss aspect

722 of biological adaptability vis á vis both environment and culture.

\section{Early-Middle Pleistocene Environmental changes}

The unique geological-climatological position of the Levant in conjunction with a

727 highly fragmented habitat contributes to creating an extremely varied and complex biotic

728 picture. The great diversity of the Southern Asian biota, both in number of species and in

729 biogeographic origin (Paleartctic, Paleotropic and Saharo-Arabian), is primarily the

730 product of the Afro-Eurasian biotic interchanges over the past 25 million years (Miocene

731 through Quaternary).

732 Since the beginning of the Miocene Southwestern Asia has been situated at the

733 crossroad between African and the Eurasian continent thus forming a wide land bridge

734 between the two regions. During different time periods, tectonic, climatic and sea level

735 changes altered the "permeability" of this land bridge. At times the region would allow

736 for animals to disperse in opposite directions and in other times the land bridge served as

737 a barrier. The Messinian event at the end of the Miocene represents a period of long

738 distance reciprocal biotic exchange due to the dramatic lowering of the Mediterranean

739 Sea level. However, since then the developing Red Sea finally limited this geographic 
740 corridor to the Levant and the southern Arabian Peninsula. Indeed, these two passages

741 functioned as a selective filter for most organisms, through which only specific species

742 could spread or pass (Tchernov, 1988; Tchernov and Belmaker, 2004).

743 The onset of the Pliocene is marked by an abrupt transgression of the

744 Mediterranean and reestablishment of the barrier between Africa and Eurasia. Thus,

745 Africa became considerably isolated from the rest of the world by the Saharo-Arabian

746 arid belt. North Africa was even further isolated from both sub-Saharan Africa and the

747 eastern Mediterranean region (Thomas, 1985). During this period, the main biotic

748 influences in the region were Asiatic, primarily from the Irano-Turanic region. These are

749 recorded mainly in Anatolian sites, which include many forest dwellers such as the

750 Cervids. The Taurus-Zagros Mountains and the Saharo-Arabian developing desert belt

751 eventually became a biogeographic barrier, particularly for laurophyllous (evergreen

752 broad-leaved) plant species (Jacobs et al., 1999), forest dwellers (Cervidae, Castoridae,

753 Gliridae and Ursidae) and aquatic animals. Hence, the transgression of the Mediterranean

754 increased the isolation of the Southwestern Asia

755 Towards the end of the Pliocene and in the Early Pleistocene, the regression of the

756 Mediterranean terminated the quasi-isolation of the region and the increase glacial-

757 interglacial cycles had their impact on the region under discussion.

Vegetation and pollen

760 The bimodal Mediterranean climate has been shown to appear in Southwest Asia

761 during the late Pliocene ca. 3.2 Ma as part of a global cooling trend and was fully

762 established by $2.8 \mathrm{Ma}$ (Suc, 1984). Unfortunately, long pollen cores that would allow for 
763 a continuous paleobotanical reconstruction throughout the Early and Middle Pleistocene

764 are rare in Western Asia in comparison to marine cores in central from the Western

765 Mediterranean Sea and the Aegean. Nonetheless, these provide a scale to which we can

766 compare results from smaller cores obtained in the region.

767 A succession scheme has been developed for the Mediterranean vegetation for

768 glacial- interglacial cycles such that glacial steppe vegetation in replaced by

769 sclerophyllous woodland (dominated by Quercus, Pinus, Betula and Juniperus) and then

770 by deciduous forests (deciduous Quercus, Carpinus, Ostrya and later on Abies and

771 Fagus), followed by a regressive phase of open woodland. Specific regional pattern

772 reflects local climatic conditions but pollen analysis in the Mediterranean basin has

773 shown that the vegetation succession follows the processional insolation cycles

774 (Tzedakis, 2007). Thus during the Early Pleistocene, while the glacial- interglacial cycles

775 were dominated by the obliquity 41 ka cycles, the succession of floral communities

776 followed a cycle roughly every $23 \mathrm{ka}$.

777 A long pollen core in Teneghi Philippon, Greece, that spans the last 1.35 million

778 years, allows us to test general trends in vegetation in relation to orbital forcing. Flora

779 reconstruction for the glacial periods were based on the minima of the AP percentage and

780 are reflected during MOIS 22, 16, 12, 10, 8 and 6 with $16(0.65 \mathrm{Ma})$ being the most

781 extensive during the past $1.35 \mathrm{Ma}$. In early periods such as MOIS 38, 40 and 42,

782 Artemisia levels were over 90\% indicating extreme aridity, however these conditions

783 were not sustained over a period longer than 10ka (Tzedakis et al., 2006).

784 The majority of pollen data is derived from late Pleistocene and Holocene

785 sediments and post date the period discussed in this study. A playnostraigraphy of the 
786 Jordan Valley (Horowitz, 2001) provides a generalized Quaternary sequence for the

787 Levant, but unfortunately is not well dated. The sequence records alternations between

788 wet and dry Mediterranean flora. The interglacial flora was poor in arboreal pollen in

789 comparison to modern day conditions. A north - south gradient indicated 3-5\% arboreal

790 pollen in the north associated with steppe elements while southern cores indicate no

791 arboreal pollen but proliferation of desert plants. In comparison, the pluvial periods or the

792 glacial flora was dominated by arboreal pollen, and of interest is the increase of pollen

793 the winter deciduous oak Quercus ithaburensis (Horowitz, 1988).

794 Pollen from archaeological sites, in spite of the time gaps, provides another angle

795 to landscape reconstructions, and the conditions that faced the early hominins. A study in

796 Dmanisi indicated a forested area with Abias, Pinus, Fagus, Alnus, Castanea, Tilia,

797 Betula, Caprinus and rarely Ulmus and Salix. Bushes and shrubs are represented by

798 rhododendron, Corylus and myrtle and the herbaceous vegetation is dominated by

799 Cyperaceae, Germineae and Polygonaceae (Dzaparidze et al., 1992) consistent with the

800 humid thermophilous broad leaf forest zone which is similar in the region today in the

801 western Caucasus (Zazanashvili et al., 2000).

802 Only few botanical remains have been retrieved from 'Ubeidiya, all from the Li

803 cycle. Macrofloral remains of fossilized leaves were discovered in the limnic laminated

804 layer III- 19. These have been identified as Pistacia lentiscus, Rhus tripratita and

805 Myriophyllum sp. (Lorch, 1966). Pollen spectrum was extracted from layer III-12,

806 analyzed by A. Horowitz (Bar-Yosef and Tchernov, 1972) indicating 82\% arboreal

807 species of which the overwhelming majorities are Quercus sp. followed by Juniperus sp.

808 and Olea sp. Non-arboreal families include Gramineae, Cruciferae and Compositae. 
809 Cyperaceae comprise $8.4 \%$ of the pollen and attest to the water habitat present at the site

810 suggesting a period more humid than today.

811 There is a small pollen spectrum from Bitzat Ruhama $(n=114)$ reflecting

812 relatively high frequencies of arboreal pollen including Quercus, Pinus, Olea and Cedrus.

813 (Zaidner, 2003b). Among the non-arboral pollen we encounter Chenopodiaceae, Palmae,

814 Poaceae and Liliaceae. The presence of cedar is indicative of a colder environment in the

815 region than the present (Zaidner, 2003b).

816 A pollen sample from the Latamne formation indicates that mountain slopes near

817 the site were forested by board leaf trees such as Quercus, Caprnius, Tilia, Juglans,

818 Ulmuss, Corylus and Betula and coniferous species such as Pinus and Cupressus

819 (Dodonov et al., 1993).

820 The wood remains of GBY suggest the presence of Mediterranean wood and plant

821 species and that the climate in the Hula valley at the time of deposition resembled the

822 seasonal Mediterranean pattern seen today. Among the dominant species are oak

823 (Quercus sp.), wild pistachio (Pistacia atlantica), wild olive (Olea europaea), plum

824 (Prunus sp.), and jujube (Ziziphus spina-christi) (Goren-Inbar et al., 2004; Werker, 2006).

825 Immersed or floating freshwater plants are common at the site and include species such as

826 Euryale ferox, Najas foveolata, Nymphoides cf. peltata, Potamogeton

827 coloratus/polygonifolius, the extinct Stratiotes intermedius, Trapa natans and apparently

828 Sagittaria sagittifolia. Bank forest taxa include wild grape (Vitis sylvestris) and ash

829 (Fraxinus syriaca).

830 Pollen analysis from this site (van Zeist and Bottema, 2009) supports the general

831 landscape reconstruction derived from wood identification specifically the presence of 
832 Quercus ithaburensis - Pistacia atlantica woodland land or park-forest. Above 400-

$833500 \mathrm{~m}$ to the west of the valley, this Tabor Oak woodland species was replaced by

834 Pistacia atlantica-Amgdalus korschinskii woodland. The overall pattern indicates that

835 the upper Jordan Valley did not undergo any significant vegetation changes as a results of

836 the glacial- interglacial periods as we see in higher latitudes and the overall vegetation as

837 observed in the wood remains as in the pollen reflects comparable environs to those of

838 today. However, oxygen and carbon stable isotope evidence derived from gastropods and

839 ostracods at GBY as well as evidence from mollusk ecology indicate a climatic shift

840 (Rosenfeld et al., 2004; Ashkenazi et al., 2009; Spiro et al., 2009) inline with global

841 climatic forcing throughout the sequence across the MBB, the paleoecological

842 reconstructions based on vegetations (pollen, wood) indicated that climatic forcing may

843 have had a stronger effect on the local hydrological regime and aquatic fauna that on the

844 terrestrial ecosystem and most notably fauna (see Kingston, 2007, for further discussion

845 of this phenomenon).

Faunal turnovers and dispersal from Africa

848 The paucity of sites from the Early and Middle Pleistocene does not allow to

849 track both inter and intra variability within each of the sub-regions during this long

850 period. There are far less sites that preserve well-dated faunal assemblages than lithic

851 localities that can be used for paleontological and paleoecological analysis. The

852 observations made on the basis of fossiliforous sites are generally correlated with the

853 European and South African sequences (Belmaker, 2009). While the actual species

854 composition within each region is different the tempo and mode of change are similar 
855 across the region and point to a secular trend of cooling through time. Data for this

856 analysis is derived from archaeological sites (see previous section for detailed description

857 of the sites) as well as a several paleontological site that yielded only faunal material.

858 The Late Pliocene is well recorded in the Caucasus such in Kvabebi, (Georgia)

859 which yielded a large assemblages indicative of a marshy and riverine habitat (Vekua,

860 1995) surrounded by open woodland environment (Agustí et al, 2009b). Similarly, the

861 Bethlehem fauna with the small assemblage of 11 mammalian species can be identified

862 as representing a humid and temperate woodland environment (Gardner and Bate, 1937;

863 Hooijer, 1958). The presence of Giraffa sp. uncovered in Bethlehem suggests an African

864 dispersal during the Late Pliocene although the poor preservation of the specimen

865 precludes identification to species (Robinson and Belmaker, in press). The presence of

866 the three-toed horse Hipparion (Hooijer, 1958) would indicate a date ca. 2.5 Ma. During

867 this time period, the Jordan rift had not formed in its current state (Horowitz, 2001),

868 which may have hindered a large dispersal from Africa. Furthermore, as previously

869 mentioned, the absence of sites prior to Bethlehem does not allow us to pinpoint the

870 precise date of this dispersal which may have occurred any time prior to that.

871 The transition from the Late Pliocene to Early Pleistocene, similarly to the

872 Olduvai dry event, indicates a shift from a more humid and wet environment to a more

873 open, partially dry and somewhat cooler conditions. The change is attested when the

874 faunal assemblages of Bethlehem and Kabevebi are compared to Dmanisi (1.8 - 1.77

$875 \mathrm{Ma}$ ) (Gabunia et al., 2000; Agustí et al, 2009b), Kotsakhuri (1.63 - 1.83 Ma) and Tsalka

876 (Vekua and Lordkipandize, 2008). While the fauna from these sites is characteristic of

877 Mediterranean temperate woodland indicated by a high proportion of cervids, an 
878 ecological shift to a more open habitat is marked by the first appearance of several taxa

879 such as the Mammoth (Mammuthus meridionalis) and the large Stenoid horse (Equus

880 stenonis).

881 A local faunal turnover can be observed between the Early Pleistocene fauna

882 dated to ca. $1.8-1.7 \mathrm{Ma}$ as represented by Dmanisi, Kostakhuri and Tsalka, and the

883 younger site of 'Ubeidiya (1.6 - 1.2 Ma). While all sites have many taxa in common, the

884 older sites exhibit a more archaic suite of species including Canis etruscus, Cervus

885 perrieri and Eucladoceros sp. replaced by the younger Canis mosbachensis and late

886 Villafranchian cervids Praemegaceros obscurus- verticornis at 'Ubeidiya. 'Ubeidiya

887 possibly represents a long sequence spanning ca. $400 \mathrm{Ka}$ and its landscape was

888 essentially Mediterranean woodland similar to that of Dmanisi as shown by the great

889 abundance of cervids and other Eurasian taxa (Belmaker, 2009). However, several new

890 taxa that appear in 'Ubeidiya are not present in the previous Late Pliocene deposit of

891 Bethlehem (ca. 2.5 Ma) and the Early Pleistocene sites in the Caucasus. These include the

892 unique suite of African taxa such as Pelorovis oldwayensis, Kolpochoerus olduvaiensis

893 and Cercopithecinae cf. Theropithecus sp. (Belmaker, 2010), which coincides with the

894 Aullan dispersal event dated to 1.8 Ma (Arribas and Palmqivst, 1999). This indicates that

895 a dispersal route from East Africa to Eurasia became available during this time or

896 immediately prior to that date.

897 The comparison between 'Ubeidiya and Dmanisi is particularly informative. With

898 the exception of the genus Homo, the Early Pleistocene sites of the Caucasus are devoid

899 of African taxa (Tappen, 2009 but see Martínez-Navarro and Palmqvist, 1995), and have

900 a high proportion of endemic species such as Bison georgicus and Struthio dmanisiensis. 
901 This suggests that during the Late Pliocene the Caucasus was isolated and this situation

902 allowed for the evolution of endemic species. However, 'Ubeidiya and the Georgian sites

903 share several taxa and specifically the jird, Parameriones obiediensis. This species was

904 identified as an endemic to 'Ubeidiya and subsequently found in Dmanisi indicating that

905 the biogeographic route connecting the two regions was open. In addition the path from

906 East Africa into the Levant was also open and led to the influx of African taxa into the

907 latter.

908 The Epivillafranchian fauna is represented by the sites of Bizat Ruhama, Evron

909 Quarry and Daquara, Latamne in the Levant, Dursunlu in Anatolia and Akhalkalaki in

910 Georgia. The archaic nature of this fauna is maintained by the presence Hipopotamus

911 behemoth in Latamne. However, a novel dispersal from Africa is attested by the arrival

912 of the suid Kolpochoerus evronensis in Evron Quarry and by Giraffa camelopardalis at

913 Latamne (Robinson and Belmaker, in press). Furthermore, the appearance of modern

914 taxa such as Dama mesopotamica and Cervus elaphus indicates a new and more modern

915 faunal composition.

916 The increased shift towards a more open, arid habitat, compared to earlier sites

917 dominated by cervids and woodland taxa, is evidenced by the increasing dominance of

918 equids and the steppe mammoth (Mammuthus trogontherii). The small faunal assemblage

919 of Bizat Ruhama (ca. 1.0 Ma) in the southern coastal plain has only bovid, equid and

920 hippo remains (Ronen et al., 1998). Evron - Quarry (ca. 1.0 Ma) although situated at the

921 western margins of the Galilee where rainfall is higher than in the south, the cervid

922 sample comprises only of four among a total of $36(11 \%)$ identified specimens, while

923 bovids are represented only by 11 specimens (30\%) (Tchernov et al., 1994). 
Akhalkalaki (0.9-0.8 Ma) in central Georgia is dominated by megacerids,

925 Stephanorhinus etruscus, Mammuthus trogontherii, Equus suessenbornensis and E.

926 altidens (Vekua, 1986, 1987; Hemmer et al., 2001; Tappen et al., 2002) and Dursunlu in

927 the generally more arid central Anatolia (1.0-0.78 Ma) is characterized by the high

928 frequency of Equus caballus mosbachensis and E. altidens (Güleç et al., 1999).

929 A later large faunal turnover is observed between the Epivillafranchian and the

930 Galerian faunas and is date dated to the Matuyama-Brunhes Boundary ca. 0.78 Ma. The

931 best record is derived from GBY. This dated to MOIS 18, is assigned to a wet and humid

932 stage apparent in the high frequency of cervids (Dama sp., Cervus cf. Cervus elaphus and

933 Megalocerni sp.) (Rabinovich et al., 2008). A small contribution of African taxa includes

934 Bos buiaensis (Martínez Navarro et al., 2009)

935 The sites of Denizli and Emirkaya-2 in Anatolia and Bear's cave, Tel Hesi and

936 'Ain Soda in the Levant are dated to the early part of the Middle Pleistocene roughly

937 between 0.5-0.43 Ma (Sen et al., 1991; Tchernov and Tsoukala, 1997; Dirks, 1998; Erten

938 et el., 2005). Taxa that appear in the region for the first time include Panthera leo, several

939 megacerines and Capreolus aff. sussenborensis while the continuation of archaic taxa

940 from earlier time periods include large taxa such as Stephanorhinus hemitoechus and Bos

941 primigenius. Unfortunately the taphonomic history of these sites precludes a detailed

942 paleoecological analysis. Bear's cave as its name implies is a carnivore den and presents

943 high frequencies of carnivore taxa and a minimal appearance of herbivore taxa, which

944 precludes an environmental reconstruction. The other sites have only scant remains.

945 Not surprisingly the assemblage of Yarimburgaz cave, situated in Thrace, the

946 European portion of modern Turkey, includes faunal elements from the Russian plains 
947 such as Lagurus transiens and Ochotona pusilla which suggest the expansion of steppe

948 environment in the southern Balkans, consistent with a cold and dry OIS 8 (von

949 Koenigswald, 1998).

950 The sites of Qesem cave, Revadim and Holon, Hayonim cave layer E, Tabun cave

951 layer E in the southern Levant are dated to the later part of the Middle Pleistocene

952 between 0.43-0.13 Ma and provide a rich faunal assemblage for MOIS 8-6. The layers

953 which dated to the earlier phase of the sequence (MOIS 7) are dominated by cervids most

954 notability Dama mesopotamica whereas from MOIS 6, the increase in the mountain

955 gazelle is noted. It has been hypothesized that the increasing frequencies of gazelle may

956 indicate a climatically driven dispersal of an African arid species into the region (Stiner et

957 al., 2004, 2009), which is supported by the presence of a single specimen of Lycaon

958 pictus in Hayonim E (Stiner et al., 2001). However, isotopic analysis of teeth of both

959 fallow deer and gazelles from the Mediterranean region from both Middle and Late

960 Pleistocene sites of Qesem, Hayonim and Meged sites did not indicate any significant

961 change in niche utilization between the ungulates, suggesting that the change in

962 abundance may be due to human hunting preferences (Rowland, 2006). During this

963 period there is no sound evidence for an additional dispersal from Africa following the

964 Mid-Brunhes event of $0.43 \mathrm{Ma}$, represented by extinction of the larger fauna (Belmaker, 965 2009).

966 The modern terrestrial ecological signature of both the flora and the fauna of the 967 region developed early in the Pleistocene. While the exact composition of species may 968 have changed throughout the last 2.5 Million years, but the overall biome structure as a

969 Mediterranean region surrounded by a more arid region in the South and East and 
970 temperate region in the north did not alter significantly. The locations and extent of the

971 borders between the sub-regions may have changed emphasizing the importance of

972 understanding the role of ecotones in the region.

973

$974 \quad$ Discussion - faunal and hominins dispersals

975 Several trends can be observed in the paleoecological sequence of Western Asia

976 during the Early and Middle Pleistocene. Within this long sequence, four major

977 observations are recognized: 1 . None of the environmental changes, and particularly in

978 the Levant, were as dramatic as those recognized in higher latitudes (e.g., temperate

979 Europe); 2. The climate changed gradually from more humid and closed habitats to more

980 dry and open ones, through minor fluctuations generally correlated with the marine

981 isotope data; 3. Punctuated faunal turnovers occurred in rough correlations with Western

982 and Eastern Europe faunal units and 4. Hominin dispersals at the current state of research

983 are not positively correlated with faunal turnovers (Table 2).

984 The evidence presented in this paper indicates that a few faunal dispersals

985 between African and Eurasia occurred throughout the Late Pliocene through the Middle

986 Pleistocene. There is a general agreement among scholars that these events were

987 generally coincident with global climate changes. The main difficulty is attributing each

988 dispersal event to the time when it took place. The reason is that the known sites and

989 assemblages, described and discussed above, do not necessarily date these events. We

990 tend to forget that the discovery of Lower Paleolithic sites is accidental and they cannot

991 be considered as a continuous chronological sequence. Not surprisingly this is the nature

992 of windows into the remote past, and one can argue that the dispersals of large mammals 
993 occurred long before their bones were uncovered in the excavated sites. Relating the

994 dispersal events to the known or conjectured age of an archaeological site may result in 995 erroneous conclusions.

996 It should be stressed that the southwestern Asian fauna was established in this 997 vast region since the Miocene and consisted of characteristic Palaearctic Eurasian 998 element. The earliest dispersal from Africa of the generally woodland browser species $999(\mathrm{n}=2)$ took place sometimes during the late Pliocene. It is recorded in the undated site of

1000 Bethlehem. The next migration was during the Early Pleistocene by several species

1001 marked by their adaptation to open grasslands $(n=5)$. Their representation in the

1002 'Ubeidiya assemblages does not necessarily indicate the date of the first arrival of these

1003 taxa. A few additional browsers arrived at the time of the Jaramillo Event $(\mathrm{n}=2)$, and an

1004 additional grassland species at the Brunhes-Matuyama $(\mathrm{n}=1)$ as well as one taxon in the

1005 Mid-Brunhes (ca. 0.43 Ma; Belmaker, 2009).

1006 The attempt to use the evidence from large mammals as a backdrop to

1007 understanding the tempo and mode of early hominin dispersals is generally unsuccessful.

1008 Contrary to what has been suggested (Martínez-Navarro et al, 2007, in press; Agustí et

1009 al., 2009a) it becomes apparent that hominin migrations into this region do not correlate

1010 with the arrivals of large mammals or specific climatic regimes. The earliest dated

1011 hominin dispersal is at the time of the Dmanisi (ca. $1.77 \mathrm{Ma}$ ) by bearers of a core and

1012 flake industry. The second, as no other Early Acheulian site was found and dated in 1013 southwestern Asia, is at 'Ubeidiya (1.6-1.2 Ma).

1014 During the Epivillafranchian, ca. 1.1 Ma, large mammalian fauna arrived in the 1015 Levant from Africa as attested by the fauna of Evron and Latamne. However, the lithic 
1016 industry of these sites does not differ from other Early Acheulian assemblages, and in the

1017 lack of specific tool-types or new knapping techniques, we see no evidence for additional

1018 migration of African hominins into southwestern Asia.

1019 The site of GBY is interpreted to be the archaeological remains of a group of

1020 hominids that migrated from Africa (Bar-Yosef, 1987; Goren-Inbar and Saragusti, 1996).

1021 The lithic industry at GBY bears an African stamp and is still a rare occurrence in the

1022 Levant in spite of large surveys (e.g. Hours, 1981). The hominins had a definite

1023 preference for employing basalt as the main raw material although flint and limestone

1024 were present in the immediate vicinity. This choice, clearly expressed in high frequencies

1025 of cleavers, indicates the African origins of this group. It has been suggested (Bar-Yosef,

$10261994,1995)$ that this move was triggered by environmental change in East Africa that

1027 occurred around the Jaramillo subchron or the BMM. Interestingly, the makers of the

1028 GBY industry, either passed away after a time span of several dozens of millennia, or

1029 simply adopted the making of bifaces from flint with similar shapes to the common ones

1030 in the Levant.

1031 Human migrations occurred along the "Levantine Corridor" as defined by the

1032 paleontologists (e.g., Thomas, 1985). The Lower Paleolithic assemblages from el-

1033 Abassieh in Cairo (Bovier-Lapierre, 1926) may indicate that the Nile Valley was a

1034 possible segment of this route. The interior of the Arabian Peninsula was not an option

1035 due to the existence of the Saharan desert belt, since the end of the Miocene. Under

1036 interglacial conditions the northern penetration of the monsoonal system drastically

1037 changed the potentials for increasing amounts of resources in eastern Sahara (e.g., 
1038 Neumann, 1989) and could have facilitated an alternative path for hominins and later

1039 Archaic Homo sapiens groups along the western shores of the Red Sea.

1040 Thus, the absence of correlation between hominin and faunal dispersals is

1041 apparent and points to different underlying mechanisms for the two phenomenon. To

1042 reiterate the point we can discuss the situation in Arabia, which is beyond the scope of

1043 this paper. Regional surveys in the Arabian Peninsula have led to the identification of

1044 find spots and the collection of lithic assemblages with and without bifaces. Bifaces are

1045 reported solely from the western margins where they are made on a variety of raw

1046 materials such as flint, basalt, and metamorphic rocks. No bifaces have yet been found in

1047 the eastern Arabia that borders the Persian Gulf. Of special interest are the reports

1048 concerning sites or find spots along the Red Sea, another potential route of hominins. The

1049 excavation at Saffaqah (Whalen et al., 1983, 1984) provided a rich Acheulian assemblage

1050 made primarily of andesite with bifaces, cleavers, and numerous flakes. The depth of the

1051 deposits that contain artifacts (ca. $0.90 \mathrm{~m})$ probably reflects repeated occupations. Farther

1052 south in Yemen, excavations of open-air sites embedded in Pleistocene formations, many

1053 of which are rich in gravels or angular rock fragments, unearthed several series of core

1054 and flake assemblages and bifaces without animal bones (Amirkhanov, 1991). In

1055 addition, surface collections clearly indicate the presence of Late Acheulian industry. If

1056 no lithics remains are found in the anterior of Arabia during the Lower Paleolithic

1057 suggesting hominin migration into this region, then the site of An Nafud (Thomas et al.,

1058 1998) dated to the Early Pleistocene exhibits many of the African taxa present in the

1059 Southern Levant (Crocuta crocuta; Pelorovis cf. oldowayensis; Oryx sp.) as well

1060 additional African alcelephines and bovids whereas Palaearctic species such as cervids 
1061 are notably absent. This would suggest that Africa fauna could disperse where early

1062 Homo could or would not. Further confirming the disjunct between the two dispersal 1063 patterns.

1064 We should therefore return to the question concerning the nature of long distance 1065 migrations of hominins, whether it was based on "leapfrog" bursts of movements or

1066 gradual spreading out of small groups. Several scholars proposed that climatic changes

1067 determined the timing, mode and motivation for the out of Africa of early Homo

1068 erectus/ergaster (Potts, 1998; Dennell, 2004). It has been suggested that the expansion of

1069 grassland habitats into higher latitudes $\left(30^{\circ} \mathrm{N}\right)$, during the Late Pliocene and Early

1070 Pleistocene climatic amelioration provided the favorite habitats that facilitated human

1071 survival (Vrba, 1988, 1995; Wynn, 2004). As the paleo-climatic information reflects

1072 alternating drier and wetter intervals it could have determined the closing and opening of

1073 natural corridors and thereby allowing Homo and other taxa to move from one region to

1074 the next (Vaks et al., 2002; Raia et al., 2006).

1075 Indeed, the Aullan dispersal event (ca. 1.8 Ma) was associated with favor

1076 ecological conditions permitting hominins and a few African taxa to reach Eurasia.

1077 However, the paleoecology of the Early Pleistocene sites across southwestern Asia

1078 (Dmanisi, 'Ubeidiya, GBY) based on both flora and fauna indicates that the hominins

1079 survived in a mixed landscape of open parkland with forested surrounding hills (van Zeist

1080 and Bottema, 2009; Belmaker, 2009; Tappen, 2009; Belmaker, in press). Moreover, the

1081 prevailing environmental conditions are not sufficient to explain the differences between

1082 the lithic industries, whether 'core and flake' in the Caucasus region or the Early

1083 Acheulian in the Jordan Valley. Probably these two particular industries reflect the 
1084 activities of different groups of hominins who by their traditional learning employed 1085 different stone artifacts.

1086 Successful adaptations to new ecological niches away from the savanna

1087 environment had its price. Probably more than one of the hominin lineages has

1088 disappeared i.e., simply died out, when they had too few members to keep a viable

1089 mating and reproductive system. Such local and temporal extinctions are possibly one of

1090 the reasons, together with low archaeological visibility, why the number of Lower

1091 Paleolithic sites, even in well-researched areas, is still so small. Therefore the current

1092 distribution of lithic industries across Eurasia is undoubtedly incomplete due to paucity of

1093 field research in several regions, indicating that there is no real cultural continuity and

1094 that what we view as a constant stream of migrants, was actually interrupted many times

1095 (e.g., Dennell, in press).

1096 Chronologically, the earliest hominins reaching southwestern Asia after leaving

1097 Africa were the makers of 'core and flake' industries, and is probably why this kind of

1098 simple way of obtaining sharp edges spread across Asia and Eastern Europe. It is not

1099 impossible that even migrants in later time (such as the makers of the Karari industry)

1100 carried the 'core and flake' production into the same areas. This would explain why the

1101 Acheulian contexts dated to $1.5 \mathrm{Ma}$ to $0.25 \mathrm{Ma}$ demonstrate interstratifications with those

1102 who manufactured cores and flakes (sometimes with additional types such as spheroids).

1103 The continuous occupation of southwestern Asia by the makers of the Acheulian

1104 industry needs to be stressed. The contrast with the neighboring regions is striking. No

1105 Acheulian sites are known from Iran, but plenty were recorded in Southern Asia (e.g.

1106 Petraglia, 1998). A few sites with bifaces are known in China beyond the "Movius line" 
1107 (e.g., Hou et al, 2000). Between the Zagros and the western margins of the Indus valley

1108 there are suitable raw materials for making bifaces, but those who needed and knew how

1109 to make these tool-types were not present in these region. Natural boundaries such as the

1110 mountain ranges of the Caucasus limited early hominin moves as shown by the

1111 decreasing numbers of Acheulian handaxes (Liubin, 2002).

1112 In brief, we have no persuasive explanation why the Acheulian is not represented

1113 in the vast area between the Zagros and Baluchistan. A similar observation concerns

1114 Eastern Europe where only 'core and flake' industries were found and stand in marked

1115 difference with the proliferation of handaxes in Western Europe.

1116 While we agree that technological innovations and their social role are also

1117 considered as an important adaptation for dispersal (Carbonell et al., 1995; Larick and

1118 Ciochon, 1996), we wonder how exactly the technological innovations assisted in the

1119 survival or organization of those early hominin groups, and in particular given the lack of

1120 correlation between lithic technology, typology and environment. Detaching a few flakes

1121 from a nodule can be done in different ways, as it often depends of the fracture

1122 mechanics of the raw material, its size, shape and volume (Hovers and Braun, 2009 and

1123 papers therein).

1124 Therefore, if we accept the notion that adaptation to a specific environment during

1125 Lower Paleolithic times, did not influence the way stone tools were shaped, we have to

1126 adopt the position that it was due to the intrinsic behavioral capacities, unique to

1127 hominins, that facilitated the moves from Africa into new territories. It should be

1128 remembered that the initial dispersal of hominins has been attributed to both

1129 morphological and behavioral characteristics such as the capacity for long distance 
1130 walking (Steudel, 1994), endurance running (Bramble and Lieberman, 2004), heat

1131 adaptation (Walker and Leakey, 1993), greater brain capacity (Aiello, 1993; Aiello and

1132 Wheeler, 1995) and social structure (Kroll, 1994). Even the release from tropical diseases

1133 that allowed for an increase in population size in higher latitudes (Bar Yosef and Belfer-

1134 Cohen, 2001), does not explain what happened to the various groups in Asia.

1135 The variability selection hypothesis states that the adaptability of hominins to a

1136 wide range of habitats and specifically to a variable climate in Africa may have provided

1137 a pre-adaptation to survival in novel environments (Potts, 1998, 2002). While we agree

1138 that the presence of hominins in a wide range of environments in Eurasia supports this

1139 hypothesis, however, this explanation is valid for the "longue durée" when a period of

1140 one million years or more is considered. In addition, hypothesizing what may constitute

1141 the pre-adaptability traits is rather intriguing. These may include an increase of resource

1142 exploitation by using of stone tools, wooden tools that did not survive, and fire. For the

1143 latter there is hardly any solid evidence prior to $0.8 \mathrm{Ma}$ in GBY (Goren-Inbar et al., 2004;

1144 Alperson-Afil and Goren-Inbar, 2007; Alperson-Afil, 2008). Additional pre-adaptations

1145 would have been the importance of high-energy foods such as meat, tubers or other

1146 vegetal sources during the initial dispersal. The increase in body and brain size required a

1147 better quality diet and often the contribution of protein seems to have been the main

1148 source (Aiello and Wheeler, 1995; Cordain et al., 2000; Aiello et al., 2001; Cordain et al.,

1149 2001; Aiello and Wells, 2002). Hence, hominins evolved to become more active hunters

1150 and gatherers when compared to their ancestors, and these capacities required larger

1151 territories (Walker and Shipman, 1996). Specifically, a high proportion of meat in the diet

1152 was seen as a critical for the success of hominins and this proposition was supported, 
1153 according to various authors, by the taphonomic analyses of faunal remains

1154 (Brantingham, 1998; Hemmer, 2000; Domínguez-Rodrigo et al., 2002; Domínguez-

1155 Rodrigo, 2002; Domínguez-Rodrigo and Pickering, 2003). The colonization of the

1156 temperate Europe after 0.7 Ma is thought as facilitated by a decrease in the number of

1157 carnivore competitors and the ability of hominins to acquire larger quantities of meat

1158 (Palombo and Mussi, 2006), although the role of large game hunting could signal more a

1159 social expression than the need for meat (J.D.Speth, personal communication).

1160 In sum, this paper provides an overview of the environmental conditions that

1161 prevailed during the Lower and Middle Pleistocene in southwestern Asia indicating that

1162 regional topographic configuration played a primary role in shaping the effects of

1163 climatic amplitude on the biotic responses of flora and fauna. The emphasis on climatic

1164 shifts and regional ecological variability is commonly seen as the sound background for

1165 the archaeological contexts and therefore facilitating the understanding hominin

1166 population dynamics. Hominins were able to disperse into regions that were beyond the

1167 their sub-tropical and tropical African homeland (Bosinski, 2006; Dennell 2009) and in

1168 routes, times and into environments unrelated to other large African taxa both carnivore

1169 and herbivore suggesting a unique biological, behavioral and cultural suite of characters

1170 which allowed them to do so. However, without a better understanding the reasons for

1171 success and failure of survival of various hominin migrant groups, and whether it

1172 depended on their ability to keep their mating and reproductive systems, we will need to 1173 resort to oversimplifications of the "human success".

1174

1175 Acknowledgements 

We would like to thank the organizers of this volume for inviting us to participate.

1177 MB is funded by the American School of Prehistoric Research at Harvard University. 1178 


\section{References}

1180 Abdul-Nayeem, M., 1990. Prehistory and Protohistory of the Arabian Peninsula. Volume I:

$1181 \quad$ Saudi Arabia. Hyderabad Publishers, Hyderabad.

1182 Agustí, J., Oms, O., Parés, J.M., Martínez-Navarro, B., Turq, A., 2000. Dating and correlation of 1183 early human occupation in the Baza Formation (Guadiz-Baza Basin, SE Spain). In:

1184 Lordkipanidze, D., Bar-Yosef, O., Otte, M. (Eds.), Early Humans at the Gates of Europe. 1185 ERAUL 92, Liège, pp. 113-122.

1186 Agustí, J., Blain, H.A., Cuenca-Bescos, G., Bailon, S., 2009a. Climate forcing of first hominid 1187 dispersal in Western Europe. Journal of Human Evolution 57, 815-821.

1188 Agustí, J., Vekua, A., Oms, O., Lordkipandize, D., Bukhsianidze, M., Kiladze, G., Rook, L., 1189 2009b. The Plio-Pleistocene succession of Kvabebi (Georgia) and the background to the 1190 early human occupation of Southern Caucasus. Quaternary Science Reviews 28, 3275$1191 \quad 3280$.

1192 Aiello, L.C., 1993. Neocortex size, group size, and the evolution of language. Current $1193 \quad$ Anthropology 34, 184-193.

1194 Aiello, L.C., Bates, N., Joffe, T., 2001. In defense of the expensive tissue hypothesis. In: Falk, 1195 D., Gibson, K.R. (Eds.), Evolutionary Anatomy of the Primate Cerebral Cortex. 1196 Cambridge University Press, Cambridge, pp. 57-78.

1197 Aiello, L.C., Wheeler, P., 1995. Expensive-tissue hypothesis: the brain and digestive system in 1198 human and primate evolution. Current Anthropology 36, 199-221.

1199 Aiello, L.C., Wells, J.C.K., 2002. Energetics and the evolution of the genus Homo. Annual $1200 \quad$ Review of Anthropology 31, 323-338. 
1201 Alperson-Afil, N., 2008. Continual fire-making by Hominins at Gesher-Benot Ya'aqov, Israel. 1202 Quaternary Science Reviews 27, 1733-1739.

1203 Alperson-Afil, N., Goren - Inbar, N., 2007. Out of Africa and into Eurasia with controlled use of 1204 fire: Evidence from Gesher Benot Ya'acov, Israel. Archaeology, Ethnology and $1205 \quad$ Anthropology of Eurasia 28, 63-78.

1206 Alperson-Afil, N., Richter, D., and Goren-Inbar, N. (2007). Phantom hearths and the use of Fire at Gesher Benot Ya'aqov, Israel. PaleoAnthropology 7, 1-15.

1208 Amirkhanov, K.A., 1991. Paleolit Iuja Arabii. Nauka, Moscow.

1209 Antón, S.C., Swisher, C.C., 2004. Early dispersals of Homo from Africa. Annual Review of $1210 \quad$ Anthropology 33, 271-296.

1211 Ariai, A., Thibault, C., 1975/77. Nouvelles précisions à propos de l'outillage paléolithique ancien 1212 sur galets du Khorassan (Iran). Paléorient 3, 101-108.

1213 Arribas, A., Palmqvist, P., 1999. On the ecological connection between saber-tooths and 1214 hominids: faunal dispersal events in the Lower Pleistocene and a review of the evidence 1215 of the first human arrival in Europe. Journal of Archaeological Science 26, 571-585.

1216 Ashkenazi, S., Klass, K., Mienis, H.K., Sprio, B., Abel, R., 2009. Fossil embryos and adult 1217 Viviparidae from the Early-Middle Pleistocene of Gesher Benot Y'aacov, Isreal: ecology, 1218 longevity and fecundity. Lethaia, 10.1111/j.1502-3931.2009.00178.x.

1219 Bar-Yosef, O., 1987. Pleistocene connections between Africa and Southwest Asia: An 1220 archaeological perspective. The African Archaeological Review 5, 29-38.

1221 Bar-Yosef, O., 1994. The Lower Paleolithic of the Near East. Journal of World Prehistory 8, $1222 \quad 211-265$.

1223 Bar-Yosef, O., 1995. The Origins of Modern Humans. In: Levy, T.E. (Ed.), Archaeology of 
Society in the Holy Land. Facts on File, New York, pp. 110-123.

1225 Bar-Yosef, O., 1998a. Early colonizations and cultural continuities in the Lower Palaeolithic of

1226 Western Asia. In: Petraglia, M.D., Korisettar, R. (Eds.), Early Human Behaviour in

1227 Global Context: The Rise and diversity of the Lower Palaeolithic record. Routledge,

$1228 \quad$ London, pp. 221-279.

1229 Bar-Yosef, O., 1998b. Jordan Prehistory: A View from the West. In: Henry, D.O. (Ed.), The

1230 Prehistoric Archaeology of Jordan. Archaeopress, Oxford, pp. 162-178.

1231 Bar-Yosef, O., Tchernov, E., 1972. On the Palaeo-Ecological History of the Site of 'Ubeidiya.

1232 Israel Academy of Sciences and Humanities, Jerusalem.

1233 Bar-Yosef, O., Goren-Inbar, N., 1993. The Lithic Assemblages of 'Ubeidiya, a Lower Paleolithic

1234 Site in the Jordan Valley. The Institute of Archaeology, The Hebrew University of

1235 Jerusalem, Jerusalem.

1236 Bar-Yosef, O., Belfer-Cohen, A., 2001. From Africa to Eurasia - early dispersals. Quaternary

1237 International 75, 19-28.

1238 Barkai, R., Gopher, A., Lauritzen, S.E., Frumkin, A., 2003. Uranium Series dates from Qesem

1239 Cave, Israel, and the end of the Lower Paleolithic. Nature 423, 977-979.

1240 Barkai, R., Gopher, A., and Shimelmitz, R. 2006. Middle Pleistocene Blade Production in the

1241 Levant: An Amudian Assemblage from Qesem Cave, Israel. Eurasian Prehistory 3, 39-

124274.

1243 Barzilai, O., Buller, A. M., and Ackermann, O. (2006). Kefar Menachem West: A Lower

1244 Paleolithic site in the Southern, Shephela, Israel. Journal of The Israel Prehistoric Society

$1245 \quad 36,7-38$.

1246 Behrensmeyer, A.K., 2006. Climate Change and Human Evolution. Science 311, 476-478. 
1247 Belmaker, M., 2006. Community structure through time: 'Ubeidiya, a Lower Pleistocene site as a 1248 case study. Ph.D. Dissertation, The Hebrew University of Jerusalem.

1249 Belmaker, M., 2009. Hominin adaptability and patterns of faunal turnover in the Lower-Middle 1250 Pleistocene transition in the Levant. In: Camps, M., Chauhan, P.R. (Eds.), A sourcebook 1251 of Paleolithic transitions: Methods, Theories and Interpretations. Springer, pp. 211-227.

1252 Belmaker, M., 2010. The presence of a large cercopithecine (cf. Theropithecus $\mathrm{sp}$.) in the 1253 'Ubeidiya Formation (Early Pleistocene 'Ubeidiya). Journal of Human Evolution 58,79$1254 \quad 89$.

1255 Belmaker, M., in press. Early Pleistocene faunal connections between Africa and Eurasia: An 1256 ecological perspective. In: Fleagle, J., Grine, F., Leakey, R., J.J, S. (Eds.), Out of Africa 1257 I: Who, Where and When. Springer. New York.

1258 Belmaker, M., Tchernov, E., Condemi, S., Bar-Yosef, J., 2002. New evidence for hominid 1259 presence in the Lower Pleistocene in the Southern Levant. Journal of Human Evolution $1260 \quad 43,43-56$.

1261 Bennett, K.D., 1997. Evolution and Ecology: The Pace of Life. Cambridge University Press, 1262 Cambridge.

1263 Braidwood, R., Howe, B., (Eds.) 1960. Prehistoric investigations in Iraqi Kurdistan. Oriental 1264 Institute, Chicago.

1265 Bosinski, G., 2006. Les premers peuplements de l'Europe centrale et de l'Est. C.R. Palevol 5, $1266 \quad 311-317$

1267 Bovier-Lapierre, R.P., 1926. Les gisements paléolithiques de la plaine de l'Abbassieh. Bulletin 1268 de l'Institut d'Égypte b, 257-275.

1269 Bramble, D.M., Lieberman, D.E., 2004. Endurance running and the evolution of Homo. Nature 
1271 Brantingham, J.P., 1998. Hominid-carnivore coevolution and invasion of the predatory guild.

1272 Journal of Anthropological Archaeology 17, 327-353.

1273 Braun, D., Ron, H., Marco, S., 1991. Magnetostratigraphy of the hominid tool-bearing Erk el 1274 Ahmar formation in the northern Dead Sea Rift. Israel Journal of Earth Sciences 40, 1911275197.

1276 Braüer, G., Schultz, M., 1996. The morphological affinities of the Plio-Pleistocene mandible 1277 from Dmanisi, Georgia. Journal of Human Evolution 30, 445-481.

1278 Butzer, K., 1958. Quaternary Stratigraphy and Climate in the Near East. Bonner Geographische 1279 Abhudlungen, Fred Dummlers Verlag,

1280 Carbonell, E., Bermudez de Castro, J.M., Arsuaga, J.L., Diez, J.C., Rosas, A., Cuenca-Bescos, 1281 G., Sala, R., Mosquera, M., Rodriguez, X.P., 1995. Lower Pleistocene Hominids and 1282 Artifacts from Atapuerca-TD6 (Spain). Science 269, 826-830.

1283 Caloi, L., Palombo, M.R., 1997. Biochronology of large mammals in the early and middle $1284 \quad$ Pleistocene on the Italian peninsula. Hystrix 9, 3-12.

1285 Chazan, M., Kolska Horwitz, L., (Eds.) 2007. Holon. A Lower Paleolithic Site in Israel. Peabody 1286 Museum of Archaeology and Ethnology, Cambridge MA.

1287 Cerling, T.E., Hay, R.L., 1986. An isotopic study of paleosol carbonates from Olduvai Gorge. $1288 \quad$ Quaternary Research 25, 63-78.

1289 Clark, J.D., 1961. Fractured Chert Specimens from the Lower Pleistocene Bethlehem Beds, $1290 \quad$ Israel. Bulletin of the British Museum 5, 73-99.

1291 Clark, J.D., 1967. The middle Acheulian site at Latamne, northern Syria. Quaternaria 9, 1-68.

1292 Copeland, L., Hours, F., 1981. La fin de l'Acheuléen et l'avènement du Paléolithique Moyen en 
Syrie. In: Cauvin, J., Sanlaville, P. (Eds.), La Préhistoire du Levant. CNRS, Paris, pp. $225-238$.

1295 Copeland, L., Hours, F., 1983. Le Yabroudien d'El Kowm (Syrie) et sa place dans le 1296 Paléolithique du Levant. Paléorient 9, 21-37.

1297 Copeland, L., Hours, F., 1989. The Hammer on the Rock: Studies in the Early 1298 Palaeolithic of Azraq, Jordan. BAR, Oxford.

1299 Cordain, L., Miller, J.B., Eaton, S.B., Mann, N., Holt, S.H.A., Speth, J.D., 2000. Plant1300 animal subsistence ratios and macronutrient energy estimations in worldwide 1301 hunter-gatherer diets. American Journal of Clinical Nutrition 71, 682-692.

1302 Cordain, L., Watkins, B.A., Mann, N.J., 2001. Fatty acid composition and energy density of 1303 foods available to African hominids. Evolutionary implications for human brain 1304 development. In: Simopoulos, A.P., Pavlou, K.N. (Eds.), Nutrition and Fitness: Metabolic 1305 Studies in Health and Disease. Karger, Basel, pp. 114-161.

1306 Danin, A., 1988. Flora and vegetation of Israel and adjacent areas. In: Yom-Tov, Y., Tchernov, E. (Eds.), The Zoogeography of Israel. The Distribution and Abundance at a

1308 Zoogeographical Crossroad. Dr. W. Junk Publishers, Dordrecht, pp.129-158.

1309 de Heinzelin, J., 1966. Geological observations near Latamne. Annales Archéologiques Arabes 1310 Syriennes 16, 115-120.

1311 Dennell, R.W., 2004. Hominid dispersals and Asian biogeography during the Lower and Early Middle Pleistocene, c. 2.0 - 0.5 Mya. Asian Perspectives 43, 205-226.

1313 de Lumley, H., Nioradze, M., Barsky, D., Cauche, D., Celiberti, V., Nioradze, G., Notter, O., D., 1314 Z., Lordkipanidze, D., 2005. les industries lithiques preoldowayennes du debut du 1315 Paléolithique inferieur du site de Dmanisi en Georgie. L'Anthropologie 109, 1-182. 
1316 Dennell, R.W., 2004. Hominid dispersals and Asian biogeography during the Lower and Early Middle Pleistocene, c. 2.0 - 0.5 Mya. Asian Perspectives 43, 205-226.

1318 Dennell, R.W., in press. "Out of Africa 1" and the evidence for hominins in Eurasia before 0.5

Domínguez-Rodrigo, M., 2002. Hunting and scavenging by early humans: the state of the debate. Journal of World Prehistory 16, 1-54.

Domínguez-Rodrigo, M., De la Torre, I., De Luque, L., Alcala, L., Mora, R., Serrallonga, J.,

1338 Domínguez-Rodrigo, M., Pickering, T.R., 2003. Early Hominid Hunting and Scavenging: A 

Zooarcheological Review. Evolutionary Anthropology 12, 275-282.

1340 Dzaparidze, V., Bosinski, G., Bugianisvili, T., Gabunia, L., Justus, A., Klopotovskaja, N., 1341 Kvavadze, E., Lordkipanidze, D., Majsuradze, G., Mgeladze, N., Nioradze, M., 1342 Pavlenisvili, E., Schminke, H.-U., Sologasvili, D., Tusabramsvili, Tvalcrelidze, M., 1343 Vekua, A., 1992. Der altpaläolithische Fundplatz Dmanisi in Georgen (Kaukasus). 1344 Jahrbuch Römisch-Germanischen Zentralmuseums Mainz 36, 67-116.

1345 Enzel, Y., Amit, R., Dayan, U., Crouvi, O., Kahana, R., Ziv, B., Sharon, D., 2008. The climatic 1346 and physiographic controls of the eastern Mediterranean over the late Pleistocene 1347 climates in the southern Levant and its neighboring deserts. Global and Planetary Change $1348 \quad 60,165-192$.

1349 Erten, H., Sen, S., Özkul, M., 2005. Pleistocene mammals from travertine deposits of the Denizli 1350 basin (SW Turkey). Annales de paléontologie 91, 267-278.

1351 Feibel, C.S., 2004. Quaternary lake margins of the Levant Rift Valley. In: Speth, J.D., Goren-

1352 Inbar, N. (Eds.), Human Paleoecology in the Levantine Corridor. Oxbow Publishers, $1353 \quad$ Oxford, pp. 21-36.

1354 Frumkin, A., Stein, M., 2004. The Sahara-East Mediterranean dust and climate connection 1355 1356 Planetary Science Letters 217, 451-464.

1357 Gabunia, L., Vekua, A., 1990. L'Évolution du paléoenvironnement au cours de l'Anthropogène 1358 en Géorgie (Transcaucasie). L'Anthropologie 94, 643-650.

1359 Gabunia, L., Vekua, A., 1995. A Plio-Pleistocene hominid from Dmanisi, East Georgia, $1360 \quad$ Caucasus. Nature 373, 509-512.

1361 Gabunia, L., Vekua, A., Lordkipanidze, D., Swisher, C.C., Ferring, R., Justus, A., Nioradze, M., 
Tvalchrelidze, M., Antón, S.C., Bosinski, G., Jöris, O., de Lumley, M.-A., Majsuradze, G., Mouskhelishvili, A., 2000. Earliest Pleistocene hominid cranial remains from Dmanisi, Republic of Georgia: taxonomy, geological setting, and age. Science 288, 1019-

Gabunia, L., de Lumley, M.-A., Vekua, A., Lordkipanidze, D., de Lumley, H., 2002. Découverte d'un nouvel hominidé à Dmanisi (Transcaucasie, Géorgie). C. R. Palevol 1, 243-253.

Gardner, E.W., Bate, D.M.A., 1937. The bone-bearing beds of Bethlehem: their fauna and industry. Nature 140, 43-433.

Geraads, D., and Tchernov, E. (1983). Fémurs humaine de Pléistocène moyen de Gesher Benot Ya'aqov (Isräl). L'Anthropologie 87, 138-141.

Gilead, D., 1970. Handaxe industries in Israel and the Near East. World Archaeology 2, 1-11.

Gilead, D., Israel, M., 1975. An Early Palaeolithic site at Kefar Menahem: Preliminary report. Tel Aviv 2, 1-12.

Ginat, H., Zilberman, E., Saragusti, I., 2003. Early Pleistocene lake deposits and Lower Paleolithic finds in Nahal (wadi) Zihor, Southern Negev desert, Israel. Quaternary Research 59, 445-458.

Gisis, I., Bar-Yosef, O., 1974. New Excavation in Zuttiyeh Cave, Wadi Amud, Israel. Paleorient

$$
2,175-180
$$

Grün, R., Schwarcz, H.P., Stringer, C.B., 1991. ESR dating of teeth from Garrod's Tabun cave collection. Journal of Human Evolution 20, 231-248.

Grün, R., Stringer, C., 2000. Tabun revisited: revised ESR chronology and new ESR and Useries analyses of dental material from Tabun C1. Journal of Human Evolution 39, 601612.

Gopher, A., Barkai, R., Shimelmitz, R., Khalaily, M., Lemorini, C., Hershkovitz, I., and Stiner, 
M. (2005). Qesem Cave: An Amudian Site in Central Israel. In "Journal of the Israel Prehistoric Society." (M. Haeven, Ed.), pp. 69-92. The Israel Prehistoric Society, Jerusalem.

1389 Goren, N., 1979. An Upper Acheulian industry from the Golan Heights. Quartär 29,30, 105-121.

1390 Goren-Inbar, N., 1985. The lithic assemblage of the Berekhat Ram Acheulian Site, Golan $1391 \quad$ Heights. Paléorient 11, 7-28.

1392 Goren-Inbar, N. (1986). A figurine from the Acheulian site of Berekhat Ram. Journal of the 1393 Israel Prehistoric Society 19, 7-12.

1394 Goren-Inbar, N., 1995. The Lower Paleolithic of Israel. In: Levy, T. (Ed.), The Archaeology of 1395 Society in the Holy Land. Leicester University Press, London, pp. 93-109.

1396 Goren-Inbar, N., Zohar, I., Ben-Ami, D., 1991. A new look at old cleavers--Gesher Benot Ya'aqov. Journal of the Israel Prehistoric Society 24, 7-33.

1398 Goren-Inbar, N., Belitzky, S., Goren, Y., Rabinovich, R., Saragusti, I., 1992a. Gesher Benot 1399 Ya'aqov - the 'Bar': an Acheulian assemblage. Geoarchaeology 7, 27-40.

1400 Goren-Inbar, N., Belitzky, S., Verosub, K., Werker, E., Kislev, M., Heimann, A., Carmi, I., 1401 Rosenfeld, A., 1992b. New discoveries at the Middle Pleistocene Acheulean site of 1402 Gesher Benot Ya'aqov, Israel. Quaternary Research 38, 117-128.

1403 Goren - Inbar, N., Saragusti, I., 1996. An Acheulian biface assemblage from Gesher Benot 1404 1405 Ya'aqov, Israel: Indications of African Affinities. Journal of Field Archaeology 23, 15-

1406 Goren - Inbar, N., Feibel, C.S., Verosub, K.L., Melamed, Y., Kislev, M.E., Tchernov, E., 1407 Saragusti, I., 2000. Pleistocene milestones on the out of Africa corridor at Gesher Benot 1408 Yaaqov, Israel. Science 289, 944-947. 
1409 Goren-Inbar, N., Alperson, N., Kislev, M.E., Simchoni, O., Melamed, Y., Ben-Nun, A., Werker,

1410 E., 2004. Evidence of hominin control of fire at Gesher Benot Ya'aqov, Israel. Science

$1411 \quad 304,725-727$.

1412 Guérin, C., Eisenmann, V., Faure, M., 1993. Les grands mammifères du gisement pléistocène 1413 moyen de Latamné (vallée de l'Oronte, Syrie). In: Sanlaville, P., Besançon, J., Copeland, 1414 L., Muhesen, S. (Eds.), Le Paléolithique de la vallée moyenne de l'Oronte (Syrie). BAR 1415 International Series 587, Oxford, pp. 169-178.

1416 Güleç, E., Howell, F.C., White, T.D., 1999. Dursunlu - A new Lower Pleistocene faunal and 1417 artifact-bearing locality in southern Anatolia. In: Ullrich, H. (Ed.), Hominid Evolution: 1418 Lifestyles and Survival Strategies. Edition Archaea, Berlin; Gelsenkirchen, Germany, pp. 1419 349-364.

1420 Gvirtzman, G., Wieder, M., Marder, O., Khalaily, H., Rabinovich, R., Ron, H., 1999. Geological 1421 and pedological aspects of an Early Paleolithic site: Revadim, Central Coastal Plain, 1422 Israel. Geoarchaeology 14, 101-126.

1423 Harrison, D.L., 1972. Mammals of Arabia. Ernst Benn, London.

1424 Harrison, D.L., Bates, P.J.J., 1991. The Mammals of Arabia. Harrison Zoological Museum, 1425 Sevenoaks, Kent.

1426 Hemmer, H., 2000. Out of Asia: a paleoecological scenario of man and his carnivorous competitors in the European Lower Pleistocene. In: Lordkipanidze, D., Bar-Yosef, O., Otte, M. (Eds.), Early Humans at the Gates of Europe. Etudes et Recherches

1430 Hemmer, H., Kahlke, R.-D., Vekua, A.K., 2001. The jaguar Panthera onca gombaszgzogensis 1431 (Kretzoi, 1938) (Carnivora: Felidae) in the late Lower Pleistocene of Akhalkalaki (South 
Georgia; Transcaucasusia) and its evolutionary and ecological significant. Geobios 34, 475-486.

1434 Hooijer, D.A., 1958. An early Pleistocene mammalian fauna from Bethlehem. Bulletin of the 1435 British Museum of Natural History, London, Geology 3, 265-292.

1436 Hooijer, D.A., 1962. Middle Pleistocene mammals from Latamne, Orontes valley. Annales 1437 Archéologiques de Syrie 11, 117-132.

1438 Horowitz, A., 1979. The Quaternary of Israel. Academic Press, New York.

1439 Horowitz, A., 1988. The quaternary environments and paleogeography in Israel. In: Yom-Tov, 1440 Y., Tchernov, E. (Eds.), The Zoogeography of Israel. Dr. W.Junks Publishers, Dordecht, $1441 \quad$ Netherlands, pp. 35-57.

1442 Horowitz, A., 2001. The Jordan Rift Valley. A. A. Balkema, Roterdam.

1443 Hou, Y., Potts, R., Yuan, B., Guo, Z., Deino, A., Wang, W., Clark, J., Xie, G., and Huang, W. 1444 (2000). Mid-Pleistocene Acheulean-like Stone Technology of the Bose Basin, South $1445 \quad$ China. Science 287, 1622-1626.

1446 Hours, F., 1975. The Lower Paleolithic of Lebanon and Syria. In: Wendorf, E., Marks, A.E. 1447 (Eds.), Problems in Prehistory: North Africa and the Levant. S.M.U. Press, Dallas, pp. $1448 \quad 249-271$.

1449 Hours, F., 1981. Le Paléolithique inférieur de la Syrie et du Liban. Le point de la question en 1450 1980. In: Sanlaville, P., Cauvin, J. (Eds.), Préhistoire du Levant. Maison de l'Orient, $1451 \quad$ Lyon, pp. 165-184.

1452 Hours, F., Le Tensorer, J.M., Muhesen, S., Yalçinkaya, I., 1983. Premiers travaux sur le site de 1453 Nadaouyeh (El-Kowm, Syrie). Paléorient 9, 5-14.

1454 Hovers, E., Braun, D.R., 2009. Interdisciplinary Approaches to the Oldowan. Springer. 
Dordrecht.

1456 Hume, G.W., 1976. The Ladizian: An Industry of the Asian Chopper-Chopping Tool Complex in 1457 Iranian Baluchistan. Dorrance and Company, Philadelphia.

1458 Issar, A., 1979. Stratigraphy and paleoclimates of the Pleistocene of central and nothern Israel. 1459 Palaeogeography, Palaeoclimatology, Palaeoecology 29, 262-280.

1460 Jacobs, B.F., Kingston, J.D., L.L., J., 1999. The origin of grass-dominiated ecosytems. Annals of 1461 the Missouri Botanical Garden 86, 590-643.

1462 Jelinek, A., 1981. The Middle Paleolithic of the Southern Levant from the Perspective of Tabun 1463 Cave. In: Cauvin, J., Sanlaville, P. (Eds.), Préhistoire du Levant. Paris: Editions du $1464 \quad$ CNRS, pp. 265-280.

1465 Jelinek, A., 1982a. The Middle Paleolithic in the Southern Levant from the Perspective of the 1466 Tabun Cave. In: Ronen, A. (Ed.), The Transition from Lower to Middle Paleolithic and 1467 the Origins of Modern Man. British Archaeological Reports, Oxford, pp. 57-104.

1468 Jelinek, A., 1982b. The Middle Paleolithic in the Southern Levant with comments on the 1469 appearance of modern Homo sapiens. In: Ronen, A. (Ed.), The Transition from Lower to 1470 Middle Paleolithic and the Origins of Modern Man. British Archaeological Reports, $1471 \quad$ Oxford, pp. 57-104.

1472 Jöris, O. (2008). "Der Alpaläolitische Fubdplatz Dmanisis, (Georgaen, Kaukasus)." Römisch1473 Germanisches Zentralmuseum, Mainz.

1474 Karkans, P., Shahack-Gross, R., Ayalon, A., Bar-Matthews, M., Barkai, R., Frumkin, A., 1475 Gopher, A., and Stiner, M. C. (2007). Evidence for habitual use of fire at the end of the 1476 Lower Paleolithic: Site-formation processes at Qesem Cave, Israel. Journal of Human $1477 \quad$ Evolution 53, 197-212. 
1478 Kikodze, Z.K., 1986. Bifas-kolon v asele Kavkaza. Vestnik Gos. Muzeja Gruzii 38, 55-69.

1479 Kingston, J.D., 2007. Shifting adaptive landscapes: progress and challenges in reconstructing

1480 early hominid environments. Yearbook of Physical Anthropology 50, 20-58.

1481 Kolska - Horwitz, L., Tchernov, E., 1989. The Late Acheulian Fauna from Oumm Zinat. Journal 1482 of the Israel Prehistoric Society $22,7 *-14^{*}$.

1483 Kroll, E.M., 1994. Behavioral implications of Plio-Pleistocene archaeological site structure. $1484 \quad$ Journal of Human Evolution 27, 1-3.

1485 Larick, R., Ciochon, R.L., 1996. The African emergence and early Asian dispersal of the genus 1486 Homo. American Scientist 84, 538-551.

1487 Laukhin, S.A., Ronen, A., Pospelova, G.A., Sharonova, Z.V., Ranov, V.A., Burdukiewicz, J.-M., 1488 Volgina, V.A., Tsatskin, A., 2001. New data on the geology and Geochronology of the 1489 Lower Palaeolithic site Bizat Ruhama in the Southern Levant. Paléorient 27, 69-80.

1490 Lemorini, C., Stiner, M., Gopher, A., R., S., Barkai, R., 2006. Use-wear analysis of an Amudian 1491 laminar assemblage from the Acheuleo-Yabrudian of Qesem Cave, Israel. Journal of $1492 \quad$ Archaeological Science 33, 921-934.

1493 Le Tensorer, J. L. (2004). Nouvelles fouilles à Hummal (El Kown, Syrie centrale) premiers resultants (1997-2001). In "From the River to the Sea: The Palaeolithic and the Neolithic

1497 Le Tensorer, J.-M., Muhesen, S., Jagher, R., 1993. Nadaouiyeh I Aïn Askar: Une grande 1498 séquence paléolithique du bassin d'El Kowm (Syrie), premiers résultats, fouilles 19891499 1992. In: Cauvin, J. (Ed.), Cahiers de l'Euphrate 7. Editions Recherche sur les $1500 \quad$ Civilisations, Paris, pp. 11-36. 
1501 Liubin, V. P. (2002). "L'Acheuléen du Caucase." ERAUL, Liège.

1502 Liubin, V.P., Bosinski, G., 1995. The earliest occupation of the Caucasus region. In: Roebroeks,

1503 W., van Kolfschoton, T. (Eds.), The Earliest Occupation of Europe. University of Leiden, $1504 \quad$ Leiden, pp. 207-253.

1505 Lorch, Y., 1966. A Pleistocene florule from the Jordan Valley. Israel Journal of Botany 15, 31$1506 \quad 34$.

1507 Lordkipanidze, D., Jashashvili, T., Vekua, A., Ponce de Leon, M., Zollokofer, C.P.E., Rightmire, 1508 G.P., Pontzer, H., Ferring, R., Oms, O., Tappen, M., Bushsianidze, M., Agusti, J., 1509 Kahlke, R.D., Kildze, G., Martinez Navaro, B., Mouskhelishvili, A., Nioradze, M., Rook, 1510 L., 2007. Postcranial evidence from early Homo from Dmanisi, Georgia. Nature 449, $1511 \quad 305-310$.

1512 Marder, O., Gvirtzman, G., Ron, H., Khalaily, H., Wieder, M., Bankirer, R., Rabinovitz, R., 1513 Porat, N., Saragusti, I., 1999. The Lower Palaeolithic site of Revadim Quarry, 1514 preliminary finds. Journal of the Israel Prehistoric Society - Mitekufat Haeven 28, 21-53.

1515 Marder, O., Milevski, I., Matskevich, Z., 2006. The handaxes of Revadim Quarry: typo1516 technological considerations and aspects of intra-site variability. In: Goren-Inbar, N., 1517 Sharon, G. (Eds.), Axe Age. Acheulian Toolmaking from Quarry to Discard. Equinox, $1518 \quad$ London, pp. 223-242.

1519 Martínez-Navarro, B., 2004. Hippos, pigs, bovids, saber-toothed tigers, monkeys, and hominids: 1520 dispersals through the Levantine corridor during late Pliocene and early Pleistocene 1521 times. In: Goren-Inbar, N., Speth, J.D. (Eds.), Human Paleoecology in the Levantine 1522 Corridor. Oxbow Books, Oxford, pp. 37-52.

1523 Martínez-Navarro, B., Palmqvist, P., 1995. Presence of the African Machairdont Megantereon 
whitei (Broom, 1937) (Felidae, Carnivora, Mammalia) in the Lower Pleistocene site of Venta Micene (Orce, Granada, Spain), with some considerations on the origin, evolution and dispersal of the genus. Journal of Archaeological Science 22, 569-582.

1527 Martínez - Navarro, B., Pérez-Carlos, J.-A., Palombo, M.R., Rook, L., Palmqvist, P., 2007. The 1528 Olduvai buffalo Pelorovis and the origin of Bos. Quaternary Research 68, 220-226.

1529 Martínez-Navarro, B., Belmaker, M., Bar-Yosef, O., 2009. The large carnivores from 'Ubeidiya 1530 (early Pleistocene, Israel): biochronological and biogeographical implications. Journal of $1531 \quad$ Human Evolution 56, 514-524.

1532 Martínez-Navarro, B., Rook, L., Papini, M., Libsekal, Y., 2009. A new species of bull from the Early Pleistocene paleoanthropological site of Buia (Eritrea): Parallelism on the dispersal 1534 of the genus Bos and the Acheulian culture. Quaternary International (in press).

1535 Marshack, A., 1997. The Berekhat Ram figurine: a Late Acheulian carving from the Middle $1536 \quad$ East. Antiquity 72, 327-337.

1537 McCown, T.D., Keith, A., 1939. The Stone Age of Mt. Carmel, Volume 2: The Fossil Human 1538 Remains from the Levalloiso-Mousterian. Oxford University Press, Oxford.

1539 Mercier, N., Valladas, H., Valladas, G., Reyss, J.L., Jelinek, A., Meignen, L., Joron, J.L., 1995.

1540 TL dates of burnt flints from Jelinek's excavations at Tabun and their implications.

1541 Journal of Archaeological Science 22, 495-510.

1542 Mercier, N., Valladas, H., Froget, L., Joron, J.L., Ronen, A., 2000. Datation par la

1543 thermoluminescence de la base du gisement paléolithique de Tabun (Mont Carmel,

1544 Israël). C. R. Acad. Sci. 330, 731-738.

1545 Minzoni-Déroche, A., Sanlaville, P., 1988. Le Paléolithique inférieur de la région de Gaziantep. 1546 Paléorient 14, 87-98. 
1547 Muhesen, S., 1985. L'Acheuléen récent évoulé de Syrie. (Ed.), BAR International Series 248, $1548 \quad$ Oxford, pp.

1549 Muhesen, S., 1993. L'Acheuléen récent évolvé de l'Oronte. In: Sanlaville, P., Besançon, J., 1550 Copeland, L., Muhesen, L. (Eds.), Le Paléolithique de la vallée moyenne de l'Oronte. 1551 BAR International Series 587, Oxford, pp. 145-166.

1552 Neumann, K., 1989. Holocene Vegetation of the Eastern Sahara: Charcoal from Prehistoric Sites. 1553 African Archaeological Review 7, 97-116.

1554 Neuville, R., 1951. Le Paléolithique et le Mésolithique de Désert de Judée. Masson et Cie, $1555 \quad$ Editeurs, Paris.

1556 Ohel, M., 1991. Prehistoric survey of the Baram Plateau. Palestine Exploration Quarterly Jan1557 June, 32-47.

1558 Opdyke, N.D., Lindsay, E., Kukla, G., 1983. Evidence for earlier date of 'Ubeidiya, Israel 1559 hominid site. Nature 304, 375.

1560 Palombo, M.R., Mussi, M., 2006. Large mammals guild at the time of the first human 1561 colonization of Europe: The case of the Italian Pleistocene record. Quaternary 1562 International 149, 94-103.

1563 Petraglia, M. D., 1998. The Lower Palaeolithic of India and its bearing on the Asian record. In 1564 "Early Human Behaviour in Global Context: the Rise and Diversity of the Lower 1565 Palaeolithic Record." (M. D. Petraglia, and R. Korisettar, Eds.), pp. 343-390. Routledge, 1566 London.

1567 Porat, N., Chazan, M., Schwarcz, H., Horwitz, L.K., 2002. Timing of the Lower to Middle 1568 Paleolithic boundary: new dates from the Levant. Journal of Human Evolution 43, 1071569 122. 
1570 Porat, N., Ronen, A., 2002. Luminescence and ESR Age Determinations of the Lower Paleolithic 1571 Site Evron Quarry, Israel. Advances in ESR Applications 18, 123-130.

1572 Potts, R., 1998. Environmental hypotheses of hominin evolution. Yearbook of Physical $1573 \quad$ Anthropology 41, 93-136.

1574 Potts, R., 2002. Complexity and adaptability in human evolution. In: Goodman, M., Moffat, A.S. 1575 (Eds.), Probing Human Origins. American Academy of Arts and Sciences, Cambridge, $1576 \quad$ MA, pp. 33-58.

1577 Rabinovich, R., Gaudzinski-Windheuser, S., Goren-Inbar, N., 2008. Systematic butchering of 1578 fallow deer (Dama) at the early middle Pleistocene Acheulian site of Gesher Benot 1579 Ya'aqov (Israel). Journal of Human Evolution 54, 134-149.

1580 Raia, P., Piras, P., Kotsakis, T., 2006. Detection of Plio-Quaternary large mammal communities 1581 of Italy. An integration of fossil faunas biochronology and similarity. Quaternary Science

1583 Rink, J.W., Bartoll, J., Schwarcz, H., Shane, P., Bar-Yosef, O., 2007. Testing the reliability of 1584 ESR dating of optically exposed buried quartz sediments. Radiation Measurements 42, $1585 \quad 1618-1626$.

1586 Rightmire, G.P., Lordkipanidze, D., Vekua, A., 2006. Anatomical descriptions, comparative 1587 studies and evolutionary significance of the hominin skulls from Dmanisi, Republic of 1588 Georgia. Journal of Human Evolution 50, 115-141.

1589 Robinson, C., Belmaker, M., In Press. The biogeography of Giraffa spp. in the Southern Levant 1590 and its implication for 'Out of Africa I'. PaleoAnthropology.

1591 Rollefson, G.O., Schnurrenberger, D., Quintero, L.A., Watson, R.P., Low, R., 1997. 'Ain Soda 1592 and 'Ain Qasiya: New Late Pleistocene and Early Holocene sites in the Azraq Shishan 
area, Eastern Jordan. In: Gebel, H.G., Kafafi, Z., O., R.G. (Eds.), The Prehistory of Jordan II, Perspectives from 1996. ex oriente, Berlin, pp. 45-58.

1595 Ron, H., Gvirtzman, G., 2001. Magnetostratigraphy of Ruhama bad-land Quaternary deposit: a new age of the Lower Paleolithic site. (Eds.), Abstracts of the Annual Meeting of the Israel Geological Society. pp. 95.

1598 Ron, H., Levi, S., 2001. When did hominids first leave Africa? New high-resolution magentostratigraphy from Erk-el-Ahmar Formation, Israel. Geology 29, 887-890.

1600 Ron, H., Porat, N., Ronen, A., Tchernov, E., Horwitz, L.K., 2003. Magnetostratigraphy of the 1601 Evron Member - Implication for the age of the Middle Acheulian site of the Evron Quarry. Journal of Human Evolution 44, 633-639.

1603 Ronen, A., 1991a. The Yiron gravel lithic assemblage, artefacts older than 2.4 Ma in Israel. Archäologisches Korrespondenzblatt 21, 159-164.

1605 Ronen, A., 1991b. The Lower Palaeolitic site Evron-Quarry in western Galilee, Israel. Sonderveröffentlichungen Geologisches Institut der Universität zu Köln 82, 187-212.

1607 Ronen, A., Inbar, M., Klein, M., Brunnacker, K., 1980. Artifact-bearing gravels beneath the 1608 Yir'on Basalt. Israel Journal of Earth Sciences 29, 221-226.

1609 Ronen, A., Burdukiewicz, J.-M., Laukhin, S.A., Winter, Y., Tsatskin, A., Dayan, T., Kulikov, 1610 O.A., Vlasov, V.K., Semenov, V.V., 1998. The Lower Palaeolithic Site Bizat Ruhama in 1611 the Northern Negev, Israel. Preliminary Report, 1996 Excavations. Archäologisches $1612 \quad$ Korrespondenzblatt RGZM 28, 163-173.

1613 Rosenfeld, A., Nathan, Y., Feldman, H.R., Goldman, S. Yechieli, S.J. and Elkin, E. 2004. 1614 Paleoecology and paleosalinity of some Pleistocene lucustrine strata in Northern Israel: 1615 Acheulian culture, Trace elements and stable isotopes of ostracode valves. Geological 
1617 Rowland, J.C., 2006. Inter-and intra- tooth isotopic variation in mammalian tooth enamel from 1618 western Israel: Implication for paleoenvironmental and paleoclimate change over the past 1619350 Kya. M.Sc. Dissertation, The University of Arizona.

1620 Sagi, A., 2005. Magnetostratigraphy of 'Ubeidiya Formation, Northern Dead Sea Transform, 1621 Israel. M.Sc. Dissertation, The Hebrew University.

1622 Sanlaville, P., 1988. Synthèse sur le paléoenvironnement. Paléorient 14, 57-60.

1623 Sanlaville, P., Besançon, J., Copeland, L., Muhesen, S., 1993. Le Paléolithique de la vallée 1624 moyenne de l'Oronte (Syrie). (Eds.), BAR International Series 587. BAR, Oxford.

1625 Sen, S., de Bonis, L., Dalfes, N., Geraads, D., Jaeger, J.J., Mazin, J.-M., 1991. Première 1626 découverte d'un site à mammifères pléistocènes dans une fissure karstique en Anatolie centrale. C.R. Acad. Sci. Paris 313, 127-132.

1628 Smith, P. E. L. (1986). Paleolithic Archaeology in Iran. American Institute of Iranian Studies. 1629 Museum University of Pennsylvania, Philadelphia.

1630 Sohn, S., Wolpoff, M.H., 1993. Zuttiyeh face: A view from the east. American Journal of $1631 \quad$ Physical Anthropology 91, 325-347.

1632 Steudel, K.L., 1994. Locomotor energetics and hominid evolution. Evolutionary Anthropology 3, $1633 \quad 42-48$.

1634 Stekelis, M., 1960. The Palaeolithic Deposits of Jisr Banat Yaqub. The Bulletin of the Research 1635 Council of Israel 9G, 61-90.

1636 Stiner, M. Clark Howell, F., Martinez-Navarro, B., Tchernov, E, and Bar-Yosef, O., 2001.

1637 Outside Africa: Middle Pleistocene Lycoan from Hayonim Cave, Israel. Bulletino della 1638 Sociate Paleontologica Italiana 40, 392-302. 
1639 Stiner, M., R. Barkai, A. Gopher, 2004. The Acheulo-Yabrudian faunas from Qese Cave (Israel):

1640 Preliminary results. PaleoAnthropolgy 2, A52

1641 Stiner, M.C., Barkai, R., Gopher, A., 2009. Cooperative hunting and meat sharing 400-200 kya

1642 at Qesem Cave, Israel. Proceedings of the National Academy of Sciences 106, 13207-

$1643 \quad 13212$.

1644 Suc, J.-P., 1984. Origin and evolution of the Mediterranean vegetation and climate in Europe.

$1645 \quad$ Nature 307, 429-432.

1646 Spiro, B., Ashkenazi, S., Mienis, H.K., Melamed, Y., Fiebel, C. Delgado, A., Stratinsky, A.

1647 2009. Climate variability in the Upper Jordan Valley around $0.78 \mathrm{Ma}$, inference from

1648 time-series stable isotopes of Viviparidae, supported by mollusk and plant paleoecology.

1649 Palaeogeography, Palaeoclimatology, Palaeoecology 282: 32-44.

1650 Taskiran, H., 1998. The Distribution of Bifaces in Anatolia. In: Otte, M. (Ed.), Préhistoire

1651 d'Anatolie: Genèse de deux mondes, Anatolian Prehistory: At the Crossroads of Two

1652 Worlds, Volume 2. Etudes et Recherches Archéologiques de l'Université de Liège, Liège,

1653 pp. 569-578.

1654 Tappen, M., 2009. The wisdom of the aged and out of Africa I. In: J.J, S., Lieberman, D.E.

1655 (Eds.), Transitions in Prehistory: Essays in Honor of Ofer Bar Yosef. American School of

1656 Prehistoric Research, pp. 24-41.85.

1657 Tappen, M., Adler, D., Ferring, C.R., Gabunia, M., Vekua, A., Swisher, C.C., 2002. Akhalkalaki:

1658 The taphonomy of an early Pleistocene locality in the Republic of Georgia. Journal of

1659 Archaeological Science 29, 1367-1391.

1660 Tchernov, E., 1987. The age of the 'Ubeidiya Formation, an early hominid site in the Jordan

1661 Valley. Israel Journal of Earth Sciences 36, 3-36. 
1662 Tchernov, E., 1988. The biogeographical history of the southern Levant. In: Yom-Tov, Y.,

1663 Tchernov, E. (Eds.), The Zoogeography of Israel. Dr. Junk Publishers, Dordrecht, pp.

$1664 \quad 159-250$.

1665 Tchernov, E., 1994. New comments on the biostratigraphy of the Middle and Upper Pleistocene 1666 of the southern Levant. In: Bar-Yosef, O., Kra, R.S. (Eds.), Late Quaternary Chronology 1667 and Paleoclimates of the Eastern Mediterranean. pp. 333-350.

1668 Tchernov, E., 1995. The earliest hominids in the Southern Levant. In: Gibert, J., Sánchez, F., 1669 Gibert, L., F., R. (Eds.), The Hominids and their Environments During the Lower and 1670 Middle Pleistocene of Eurasia. Ayuntameinto de Orce, Granada, pp. 389-406.

1671 Tchernov, E., Volokita, M., 1986. Insectivores and Primates from the early Pleistocene of 1672 'Ubeidiya Formation. In: Tchernov, E. (Ed.), Les Mammiféres du Pléistocène Inférieur, 1673 de la Vallée du Jourdain a Oubéidiyeh. Association Paléorient, Paris, pp. 54-62.

1674 Tchernov, E., Kolska Horwitz, L., Ronen, A., Lister, A., 1994. The faunal remains from Evron 1675 Quarry in relation to other Paleolithic hominid sites in the Southern Levant. Quaternary $1676 \quad$ Research 42, 328-339.

1677 Tchernov, E., Tsoukala, E., 1997. Middle Pleistocene (Early Toringian) carnivore remains from $1678 \quad$ Northern Israel. Quaternary Research 48, 122-136.

1679 Tchernov, E., Belmaker, M., 2004. The biogeographic history of the fauna in the Southern 1680 Levant and the correlation with climatic change. In: Dolev, A., Perevolototsky, A. (Eds.),

1683 Thomas, H., 1985. The Early and Middle Miocene land connection of the Afro-Arabian plateau 1684 and Asia: A major event for hominid dispersal? In: Delson, E. (Ed.), Ancestors: The Hard 
1686 Thomas, H., Geraads, D., Janjou, D., Vaslet, D., Memesh, A., Billiou, D., Boucherns, H., 1687 Dobigny, G., Eisenmann, V., Gayet, M., Lapparent De Broin, F., Petter, G., Halawani, 1688 M., 1998. First Pleistocene faunas from the Arabian Peninsula: An Nafud desert, Saudi 1689 Arabia. Comptes rendue de l'Academie des science, série II de la terre et des planètes $1690 \quad 326,145-152$.

1691 Tobias, P., 1966a. A Member of the Genus Homo from 'Ubeidiya. Publications of the Israel 1692 Academy of Sciences and Humanities, Jerusalem.

1693 Tobias, P.V., 1966b. Fossil hominid remains from 'Ubeidiya, Israel. Nature 211, 130-133.

1694 Tzedakis, P.C., 2007. Seven ambiguities on the Mediterranean paleoenvironmental narrative.

1695 Quaternary Science Reviews 26, 2042-2066.

1696 Tzedakis, P.C., Hooghiemstra, H., Pälike, H., 2006. The last 1.35 million years at Tenaghi

1697 Philippon: revised chronostratigraphy and long-term vegetation trends. Quaternary $1698 \quad$ Science Reviews 25, 3416-3430.

1699 Vaks, A., Bar-Matthews, M., Ayalon, A., Frumkin, A., 2002. Paleoclimate Conditions in the 1700 Central and Northern Negev Desert During the Pleistocene. 2002 Ma'agan Israeli $1701 \quad$ Geological Society Abstracts 125.

1702 van Zeist, W., Bottema, S., 2009. A palynological study of the Acheulian site of Gesher Benot 1703 Ya'aqov, Israel. Vegetation History and Archaeobotany 18, 105-121.

1704 Vandermeersch, B., 1995. Le rôle du Levant dans l'évolution de l'humanité au Pléistocene 1705 supérieur. Paléorient 21, 25-34.

1706 Vekua, A., 1986. Pleistocene Mammalian Fauna of Akhalkalaki (Southern Georgia, USSR). 1707 Paleontolographia Italica 74, 63-96. 
1708 Vekua, A.K., 1987. Lower Pleistocene Mammalian fauna of Akhalkalaki (Southern Georgia, 1709 USSR). Palaeontographica Italica 74, 63-96.

1710 Vekua, A., 1995. Die Wirbeltierfauna des Villafranchium von Dmanisi und ihr

1711 biostratigraphische Bedeutung. Jahrbuch des Roemisch-Germanischen Zentralmuseums, $1712 \quad$ Mainz.

1713 Vekua, A., Lordkipandize, D., 2008. The history of vertebrate fauna in Eastern Georgia. Bulletin 1714 of the Georgian National Academy of Sciences 2, 149-155.

1715 Verosub, K., Tchernov, E., 1991. Resultats préliminaires de l'étude magnétostratigraphique d'une 1716 séquence sédimentaire à l'industrie humaine en Israël. In: Vandermeersch, B. (Ed.), Les 1717 premiers peuplements de l'Europe. C.N.R.S, Paris, pp. 237-242.

1718 von Koenigswald, W., 1998. Preliminary report on the middle Pleistocene small mammal fauna 1719 from Yarimburgaz cave in Turkish Thrace. Eiszeitalter und Gegenwart 48, 162-169.

1720 Vrba, E.S., 1988. Late Pliocene climatic events and hominid evolution. In: Grine, F.E. (Ed.), 1721 Evolutionary History of the "Robust" Australopithecines. Aldine de Gruyter, New York, 1722 pp. $405-426$.

1723 Vrba, E.S., 1995. The fossil record of African antelopes (Mammalia, Bovidae) in relation to 1724 human evolution and paleoclimate. In: Vrba, E., Denton, G., Partridge, T., Burckle, L. 1725 (Eds.), Paleoclimate and Evolution, with Emphasis on Human Origins. Yale University 1726 Press, New Haven, pp. 385-424.

1727 Walker, A., Leakey, R., (Eds.) 1993. The Nariokotome Homo erectus Skeleton. Harvard $1728 \quad$ University Press, Cambridge.

1729 Walker, A., Shipman, P., 1996. The Wisdom of Bones: In Search of Human Origins. Knopf, $1730 \quad$ New York. 
1731 Weinstein-Evron, M., Bar-Oz, G., Zaidner, Y., Tsatskin, A., Druck, D., Porat, N., Hershkovitz,

1732 I., 2003. Introducting Misliya Cave, Mount Carmel, Israel: a new continuous

1733 Lower/Middle Paleolithic sequence in the Levant. Eurasian Prehistory 1, 31-55.

1734 Werker, E. (2006). 780,000-year old wood from Gesher Benot Ya'aqov, Israel. Israel Journal of $1735 \quad$ Plant Sciences 54, 291-300.

1736 Whalen, N., Sindi, H., Wahida, G., Siraj-Ali, J.S., 1983. Excavations of Acheulean sites near 1737 Saffaqah in Ad-Dawadmi 1302-1982. Atlal 7, 9-21.

1738 Whalen, N., Siraj-Ali, J.S., Davis, W., 1984. Excavations of Acheulean sites near Saffaqah, 1739 Saudi Arabia, 1403 AH 1983. Atlal 8, 9-24.

1740 Wynn, J.G., 2004. Influence of Plio-Pleistocene aridification on human evolution: Evidence from 1741 paleosols of the Turkana Basin, Kenya. American Journal of Physical Anthropology 123, $1742 \quad 106-118$

1743 Zaidner, Y., 2003a. The use of raw material at the Lower Palaeolithic site of Bizat Ruhama, 1744 Israel. In: Burdukiewicz, J.M., Ronen, A. (Eds.), Lower Palaeolithic Small Tools in 1745 Europe and the Levant. BAR, Oxford, pp. 121-131.

1746 Zaidner, Y., 2003b. The lithic assemblage of Bizat Ruhama: Lower Paleolithic site in southern 1747 coastal plain, Israel. M.Sc. Dissertation, Haifa University, Israel.

1748 Zaidner, Y., Ronen, A., Burdukiewicz, J.,-M., 2003. L'industrie microlithique de Palélithique 1749 inférior de Bizat Ruhama, Israël. L'Anthrolopologie 107, 203-222.

1750 Zarins, J., Ibrahim, M., Potts, D., Edens, C., 1979. Saudi Arabian archaeological reconnaissance 1751 1978: The preliminary report on the third phase of the comprehensive archaeological 1752 survey program - the central province. Atlal 3, 9-38.

1753 Zarins, J., Whalen, N., Ibrahim, M., al Jawad, A., Khan, M., Khan, M., 1980. Saudi Arabian 
1754 archaeological reconnaissance 1979: Preliminary report on the central and southwest 1755 provinces survey. Atlal 4, 9-36.

1756 Zarins, J., Rahbini, A., Kamal, M., 1982. Preliminary report on the archaeological survey of the $1757 \quad$ Riyadh area. Atlal 6, 25-38.

1758 Zazanashvili, N., Gagnidze, R., Nakhutsrishvili, G., 2000. Main types of vegetation zonation on 1759 the mountains of the Caucasus. Proceedings IAVS symposium pp. 214-217.

1760 Zhu, R.X., An, Z., Potts, R., Hoffman, K.A., 2003. Mangenetostraigraphic dating of early 1761 humans in China. Earth Science Reviews 61, 341-359.

1762 Zohary, D., 1973. Geobotanical foundations of the Middle East. Gustav Fisher, 1763

1764

1765 


\section{Figure legends}

1766

1767 Figure 1: Location of major sites mentioned in the texts. Subfigure A includes the near east.

1768 Subfigure B includes the Levant and is denoted in the box within subfigure A.

1769

1770 

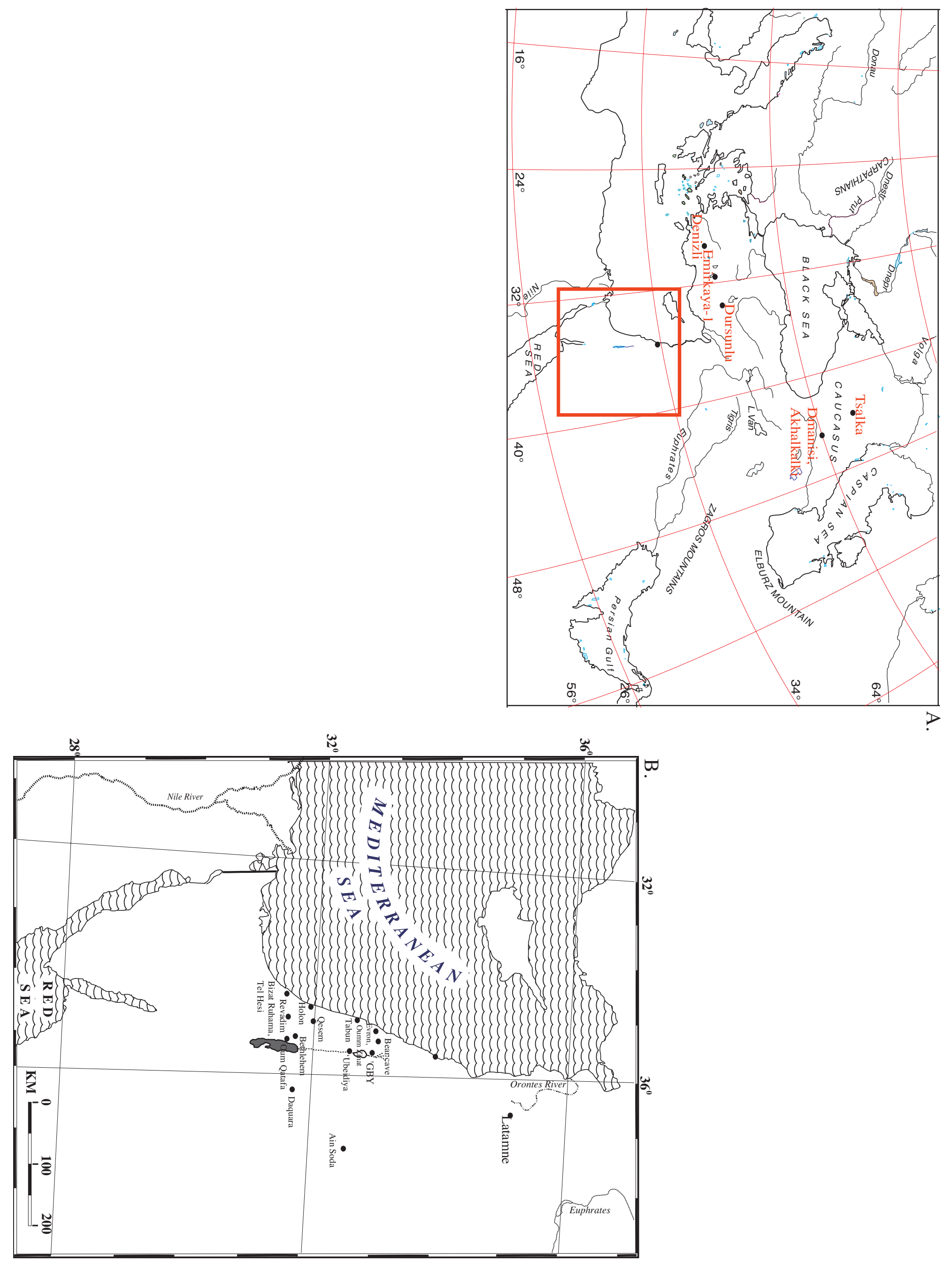
Table 1a: A summary of the distribution of the main carnivores in the Early to Middle Pleistocene of the Near East. References are mentioned in the texts. X denoted presence.

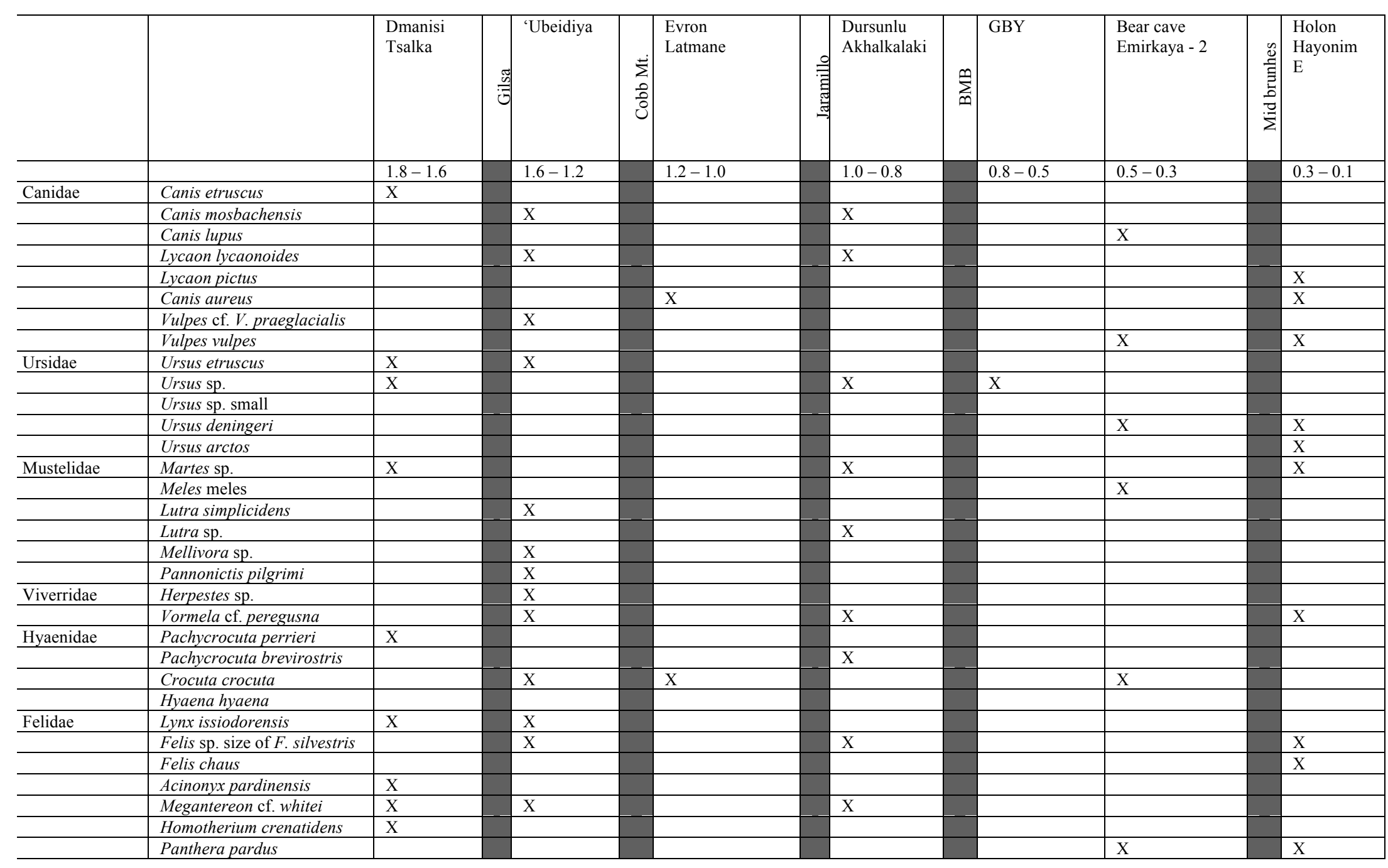


\begin{tabular}{|l|l}
\hline Panthera leo & \\
\hline Panthera gombaszoegensis & $\mathrm{X}$ \\
\hline
\end{tabular}

X

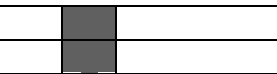


Table 1b: A summary of the distribution of the main ungulates in the Early to Middle Pleistocene of the Near East. References are mentioned in the text. X denoted presence.

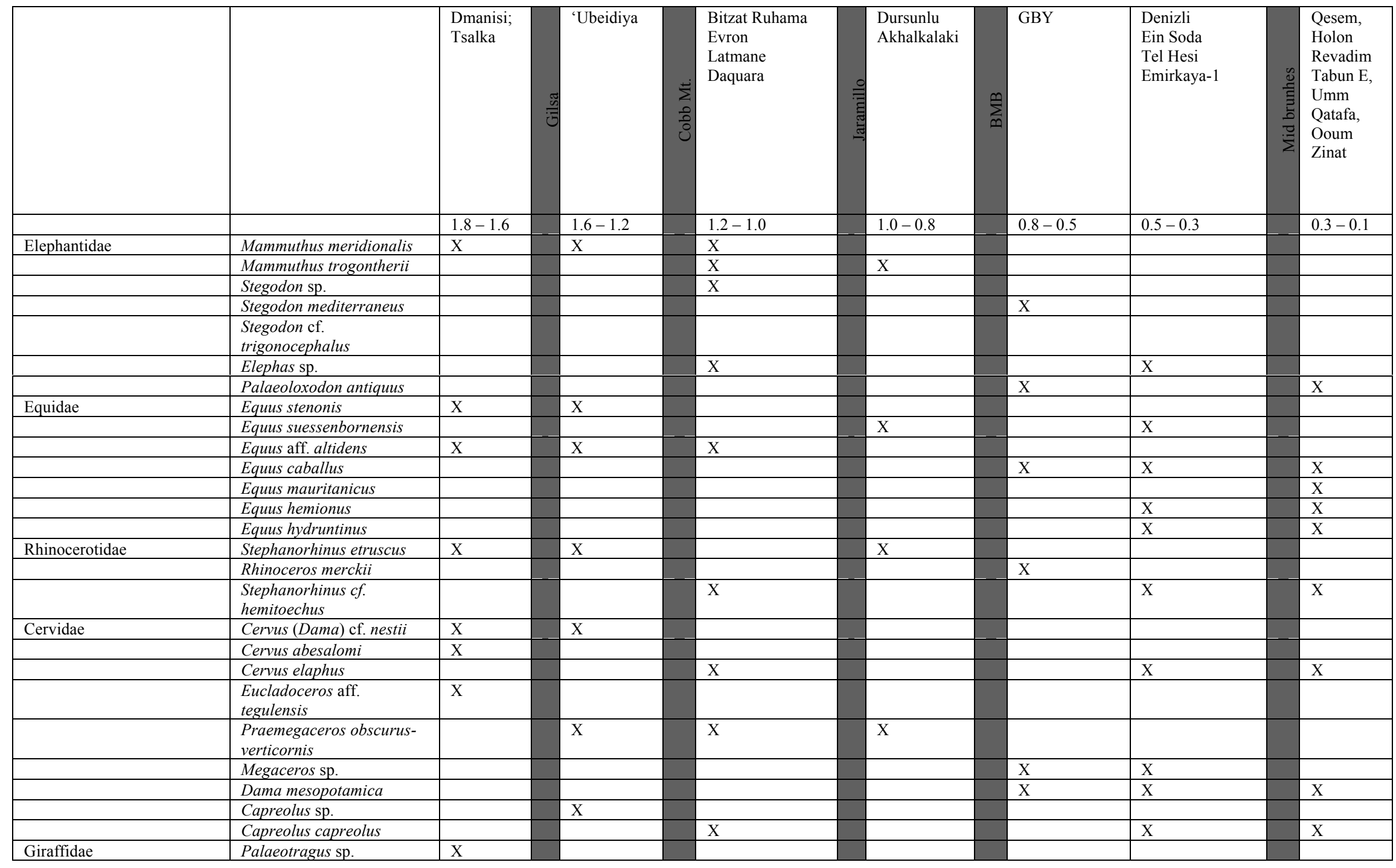




\begin{tabular}{|c|c|c|c|c|c|c|c|c|}
\hline & Giraffa sp. & & $\mathrm{X}$ & & & & & \\
\hline & Giraffa camelopardalis & & & $\mathrm{X}$ & & & & \\
\hline \multirow[t]{20}{*}{ Bovidae } & Bison georgicus & $\mathrm{X}$ & & & & & & \\
\hline & Leptobos sp. & & $\mathrm{X}$ & & & & & \\
\hline & Bison sp. & & & $\mathrm{X}$ & $\mathrm{X}$ & $\mathrm{X}$ & $\mathrm{X}$ & \\
\hline & Bos primigenius & & & $\mathrm{X}$ & $\mathrm{X}$ & $\mathrm{X}$ & $\mathrm{X}$ & $\mathrm{X}$ \\
\hline & Gallogoral meneghini & $\mathrm{X}$ & & & & & & \\
\hline & Pelorovis oldowayensis & & $\mathrm{X}$ & & & & & \\
\hline & Bos buiaensis & & & & & $\mathrm{X}$ & & \\
\hline & ? Sinoreas sp. & & & & $\mathrm{X}$ & & & \\
\hline & Capra sp. & & & & & $\mathrm{X}$ & & \\
\hline & Capra ibex & & & & & & $\mathrm{X}$ & $\mathrm{X}$ \\
\hline & Capra aegagrus & & & & & & & $\mathrm{X}$ \\
\hline & Capra dalii & $\mathrm{X}$ & & & & & & \\
\hline & Caprini indet. & & & & & $\mathrm{X}$ & & \\
\hline & Ovibovini indet & $\mathrm{X}$ & & & & $\mathrm{X}$ & & \\
\hline & Pontoceros sp. & $\mathrm{X}$ & $\mathrm{X}$ & $\mathrm{X}$ & & & & \\
\hline & Antilopini indet. & $\mathrm{X}$ & $\mathrm{X}$ & & & & & \\
\hline & Gazella sp. & & $\mathrm{X}$ & $\mathrm{X}$ & & $\mathrm{X}$ & & \\
\hline & Gazella cf. gazella & & & & & & $\mathrm{X}$ & $\mathrm{X}$ \\
\hline & Oryx cf. gazella & & $\mathrm{X}$ & & & & & \\
\hline & Alcelaphus buselaphus & & & $\mathrm{X}$ & & & & $\mathrm{X}$ \\
\hline Camelidae & Camelus sp. & $\mathrm{X}$ & $\mathrm{X}$ & $\mathrm{X}$ & & & & \\
\hline \multirow[t]{4}{*}{ Suidae } & Kolpochoerus olduvaiensis & & $\mathrm{X}$ & & & & & \\
\hline & Kolpochoerus evronensis & & & $\mathrm{X}$ & & & & \\
\hline & Sus strozzi & & $\mathrm{X}$ & & & & & \\
\hline & Sus scrofa & & & & & $\mathrm{X}$ & $\mathrm{X}$ & $\mathrm{X}$ \\
\hline \multirow[t]{4}{*}{ Hippopotamidae } & Hippopotamus georgicus & $\mathbf{X}$ ? & & & $\mathrm{X}$ & & & \\
\hline & Hippopotamus behemoth & & $\mathrm{X}$ & $\mathrm{X}$ & & & & \\
\hline & Hippopotamus gorgops & & $\mathrm{X}$ & & & & & \\
\hline & Hippopotamus antiquus & & & $\mathrm{X}$ & & $\mathrm{X}$ & & $\mathrm{X}$ \\
\hline \multirow[t]{2}{*}{ Primates } & Macaca sylvanus & & $\mathrm{X}$ & & & & & \\
\hline & $\begin{array}{l}\text { Cercopithecidae cf. } \\
\text { Theropithecus }\end{array}$ & & $\mathrm{X}$ & & & & & \\
\hline
\end{tabular}


Table 2: Faunal and hominin dispersal from Africa to Eurasia in different biozones

\begin{tabular}{|c|c|c|c|c|c|c|c|c|}
\hline 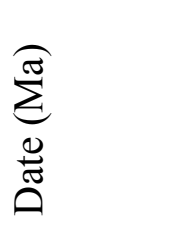 & $\stackrel{n}{\infty}$ & 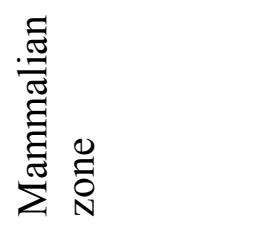 & 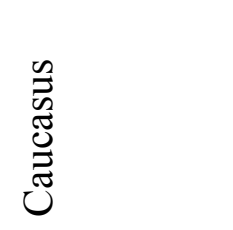 & 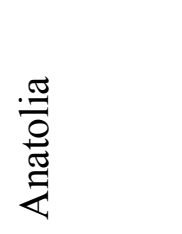 & 䓌 & 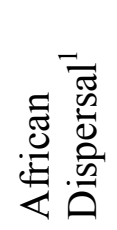 & 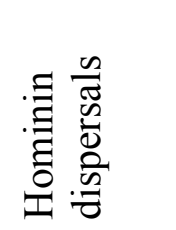 & 祍: \\
\hline 2.5 & & $\begin{array}{l}\text { Early } \\
\text { Villafranchian }\end{array}$ & Kvebebi & & Bethlehem & $\mathrm{N}=2$ & & \\
\hline 1.8 & & $\begin{array}{l}\text { Middle } \\
\text { Villafranchian }\end{array}$ & $\begin{array}{l}\text { Dmanisi, } \\
\text { Tsalka }\end{array}$ & & & & $\begin{array}{l}\text { Dispersal } \\
\text { event }\end{array}$ & $\begin{array}{l}\text { Core and } \\
\text { flake }\end{array}$ \\
\hline $1.6-1.2$ & & $\begin{array}{l}\text { Late } \\
\text { Villafranchian }\end{array}$ & & & 'Ubeidiya & $\mathrm{N}=5$ & $\begin{array}{l}\text { Dispersal } \\
\text { event }\end{array}$ & $\begin{array}{l}\text { Early } \\
\text { Acheulian }\end{array}$ \\
\hline $1.1-1.0$ & & $\begin{array}{l}\text { Epi- } \\
\text { villafranchian }\end{array}$ & $\begin{array}{l}\text { Akhalkalaki } \\
\text { Takshe }\end{array}$ & Dursunlu & $\begin{array}{l}\text { Daquara, } \\
\text { Latamne, } \\
\text { Evron, }\end{array}$ & $\mathrm{N}=2$ & & \\
\hline 0.8 & 19 & Gallerian & & & GBY & $\mathrm{N}=1$ & $\begin{array}{l}\text { Dispersal } \\
\text { event }\end{array}$ & Acheulian \\
\hline 0.5 & & & & $\begin{array}{l}\text { Danizli, } \\
\text { Emirkaya } \\
-2, \\
\text { Bear } \\
\text { Cave, }\end{array}$ & $\begin{array}{l}\text { Revadim } \\
\text { Holon, } \\
\text { Ein Soda, } \\
\text { Tel Hesi }\end{array}$ & & & \\
\hline $0.4-0.3$ & $8-9$ & Auralian & & & $\begin{array}{l}\text { Qesem, } \\
\text { Revadim } \\
\text { Tabun E }\end{array}$ & & & $\begin{array}{l}\text { Achelo- } \\
\text { Yaburidian }\end{array}$ \\
\hline $0.3-0.13$ & $7-6$ & & & & $\begin{array}{l}\text { Hayonim } \\
\text { E, Misliya }\end{array}$ & & & $\begin{array}{l}\text { Early } \\
\text { Mousterian }\end{array}$ \\
\hline
\end{tabular}

\footnotetext{
${ }^{1}$ Number of species that left Africa
} 
